\title{
Structural, Theoretical and Biological Studies of (Z)-3-Amino-N-(3-Amino Pyrazine-2-Carbonyl) Pyrazine-2-Carbohydrazonic Acid (APA; L) and Its $\mathrm{Cu}^{2+}, \mathrm{Co}^{2+}, \mathrm{Pt}^{4+}$ and $\mathrm{Pd}^{2+}$ Chelates
}

\author{
Mosaad R. Mlahi' ${ }^{1}$ Mohsen M. Mostafa ${ }^{2 *}$ \\ ${ }^{1}$ Faculty of Science, Department of Chemistry, Amran University, Amran, Yemen \\ ${ }^{2}$ Faculty of Science, Department of Chemistry, Mansoura University, Mansoura, Egypt \\ Email: ^amohsenmostafa@Yahoo.com
}

How to cite this paper: Mlahi, M.R. and Mostafa, M.M. (2021) Structural, Theoretical and Biological Studies of (Z)-3-AminoN-(3-Amino Pyrazine-2-Carbonyl) Pyrazine2-Carbohydrazonic Acid (APA; L) and Its $\mathrm{Cu}^{2+}, \mathrm{Co}^{2+}, \mathrm{Pt}^{4+}$ and $\mathrm{Pd}^{2+}$ Chelates. Open Journal of Inorganic Chemistry, 11, 145-175. https://doi.org/10.4236/ojic.2021.114010

Received: August 4, 2021

Accepted: October 24, 2021

Published: October 27, 2021

Copyright $\odot 2021$ by author(s) and Scientific Research Publishing Inc. This work is licensed under the Creative Commons Attribution International License (CC BY 4.0).

http://creativecommons.org/licenses/by/4.0/

\begin{abstract}
New chelates derived from the novel ligand, (Z)-3-amino-N-(3-amino pyrazine2-carbonyl)pyrazine-2-carbohydrazonic acid (APA, L), with $\mathrm{Cu}^{2+}, \mathrm{Co}^{2+}, \mathrm{Pt}^{4+}$ and $\mathrm{Pd}^{2+}$ salts were investigated. The results suggest that APA acts as mononegative tridentate in the case of $\mathrm{Cu}^{2+}$, binegative tetradentate in the case of $\mathrm{Co}^{2+}$ and as mononegative bidentate towards $\mathrm{Pt}^{4+}$ and $\mathrm{Pd}^{2+}$ chelates. The results of the corrected $\mu_{\text {eff }}$ and spectral suggest the structures of the isolated chelates. The results of the corrected $\mu_{\text {eff }}$ and spectral suggest the geometries of the isolated chelates. Molecular modeling is deduced and chemical reactivity, energy components for chelates and also MEP for APA is illustrated. In Vitro, the SOD and radical scavengers like activity of the synthesized compounds Hep G2 liver cancer cells and cytotoxic activity were checked. Metal chelates show potent anti-oxidative activity. The results of cytotoxic activity assay against hepatocellular carcinoma cell line Hep $\mathrm{G} 2$ confirmed that $\mathrm{Pt}^{4+}$ complex has the highest value, while $\mathrm{APA}, \mathrm{Cu}^{2+}, \mathrm{Co}^{2+}$ and $\mathrm{Pd}^{2+}$ chelates have no significant cytotoxic activity.
\end{abstract}

\section{Keywords}

Aminopyrazine, Density Function Theory Calculations, Antioxidant and Cytotoxic Activity, Biological Studies

\section{Introduction}

Heterocyclic compounds containing nitrogen show multidirectional pharmacological activity like diuretic [1] [2], antitumor [3] [4] [5] [6] and hypotensive [7] 
[8] [9]. On searching of the anticipated biologically active compounds, we had cared in 3-aminopyrazin-2-hydrazide [10]. The pyrazine derivatives are also utilized in many pharmaceuticals as well as the products used for plant protection [11] [12]. Our research devotes especially to the compounds having potential tuberculosis activity [10]. Pyrazinamide, as an example of pyrazine derivatives, is well known as an effective therapeutics in infections caused by M. tuberculosis. The pervasive incidence of simple pyrazine molecules in nature, especially in the flavors of many food systems, their effectiveness at very low concentrations as well as the still increasing applications of synthetic pyrazines in the flavor and fragrance industry are queried for the high interest in these compounds [13]. Specific pyrazines, especially dihydropyrazines, are essential for all forms of life due to their DNA strand breakage activity and/or by their influencing of apoptosis [14]. Synthetic pyrazine derivatives have also been advantageous as drugs (antiviral, anticancer, antimycobacterial, etc.) fungicides, and herbicides [15]. Furthermore, 3-amino-6-chloro-pyrazine-6-carboxylic acid, as an example of a simple pyrazine compound, has shown an anti-auxin behavior. The significance of the pyrazine (1,4-diazine) ring for the activity of the biological herbicides can be assessed primarily according to the size of the investigated molecules. In this work, the potent active antioxidant and cytotoxic activities of the separated chelates on HepG2 liver cancer cells have been examined. The structures of the resulting APA and its chelates have been achieved on the basis of elemental analyses, spectral (IR, UV-vis., ${ }^{1} \mathrm{H}-\mathrm{NMR},{ }^{13} \mathrm{C}$-NMR mass), magnetic and thermal measurements and supported by Density Functional Theory (DFT) method.

The goal of our work is to check in detail the chelation behavior of the novel (Z)-3-amino-N-(3-aminopyrazine-2-carbonyl) pyrazine-2-carbohydrazonic acid (APA) and its chelates derived from $\mathrm{Cu}^{2+}, \mathrm{Co}^{2+}, \mathrm{Pt}^{4+}$ and $\mathrm{Pd}^{2+}$ ions, embedding structural articulation and molecular modeling of both APA and its chelates. Moreover, our attention is directed to evaluate the antioxidant and anticancer activity of the ligand as well as the detached chelates.

\section{Experimental}

\subsection{Materials}

All the chemicals are of AR quality and used as supplied. Elemental analyses (C, $\mathrm{H}, \mathrm{N}$ ), chloride and metal contents were determined by conventional methods [16]. Spectral and TGA studies were carried as reported in our previous work [17] [18]. Also, all the chemicals used in biological activity were reported earlier [18]. The diamagnetic corrections were determined using Pascal's constants [19].

\subsection{Synthesis of the Ligand (APA) and Its Complexes}

\subsubsection{Synthesis of (Z)-3-amino-N-(3-aminopyrazine-2-carbonyl) pyrazine-2-carbo-hydrazonic Acid (APA)}

The novel organic compound, (Z)-3-amino-N-(3-aminopyrazine-2-carbonyl) pyrazine-2-carbohydrazonic acid (Figure 1(a), Figure 1(b)), was synthesized by adding slowly drop by drop of methyl 3-aminopyrazine-2-carboxylaste $(1.53 \mathrm{~g}, 0.01$ 
<smiles>C=CC=CN=C(O)c1nccnc1N/N=C(\O)c1nccnc1N</smiles>

(a)<smiles>NNC(=O)c1nccnc1N</smiles>

(b)

(c)

Figure 1. (Z)-3-amino-N-(3-aminopyrazine-2-carbonyl) pyrazine-2-carbohydrazonic acid (APA) in the keto (a) and enol (b) forms. (c) Structure of 3-amino-pyrazin-2-carbohydrazide.

mol) in absolute ethanol to $\mathrm{N}_{2} \mathrm{H}_{4}(8 \mathrm{~mL})$. A pale yellow solid of APA was obtained by continuous stirring of the reaction mixture on a heater at $60^{\circ} \mathrm{C}$ for 1.5 h. Doubtless the addition of methyl 3-aminopyrazine-2-carboxylate to excess hydrazine hydrate assists of the formation of APA and excludes the formation of 3-amino-pyrazin-2-carbohydrazide (Figure 1(c)). The novel product was obtained and collected by filtration followed by continuous washing several times with hot EtOH and ether. The isolated product was kept in a drier over anhydrous phosphorous pentaoxide. APA was recrystallized from absolute EtOH (Yield: $60 \%)$. The purity of APA was checked by spectral, TLC and its melting point $\left(159^{\circ} \mathrm{C}-160^{\circ} \mathrm{C}\right)$.

\subsubsection{Synthesis of $\mathrm{Cu}^{2+}, \mathrm{Co}^{2+}, \mathrm{Pt}^{4+}$ and $\mathrm{Pd}^{2+}$ Chelates}

Metal chelates were acquired by reacting $0.001 \mathrm{~mol}$ of APA $(0.274 \mathrm{~g}, 0.001 \mathrm{~mol})$ to metal chlorides $\left(\mathrm{CuCl}_{2} \cdot 2 \mathrm{H}_{2} \mathrm{O} ; 0.17 \mathrm{~g}, \mathrm{CoCl}_{2} \cdot 6 \mathrm{H}_{2} \mathrm{O} ; 0.24 \mathrm{~g}, \mathrm{PtCl}_{4} ; 0.34 \mathrm{~g} ; \mathrm{PdCl}_{2}\right.$; $0.18 \mathrm{~g}$ ) in 1:1 $\mathrm{M}$ ratio. The $\mathrm{pH}$ of the solution was optimized at 2, 3, 2 and 5, respectively. The isolated metal chelates with the general formulae, $\mathrm{C}_{10} \mathrm{H}_{13} \mathrm{Cu}_{2} \mathrm{~N}_{8} \mathrm{O}_{4} \mathrm{Cl}_{3}$, $\mathrm{C}_{12} \mathrm{H}_{18} \mathrm{Co}_{2} \mathrm{~N}_{8} \mathrm{O}_{5} \mathrm{Cl}_{2}, \mathrm{C}_{14} \mathrm{H}_{25} \mathrm{PtN}_{8} \mathrm{O}_{6} \mathrm{Cl}_{3}$ and $\mathrm{C}_{11} \mathrm{H}_{14} \mathrm{PdN}_{8} \mathrm{O}_{7 / 2} \mathrm{Cl}$, were isolated by filtration, rinsed continuously with $\mathrm{EtOH}$ and ether. The products were kept in a drier over $\mathrm{P}_{4} \mathrm{O}_{10}$. All the chelates are freely soluble in polar solvents and quite stable in air.

\subsection{Biological Studies}

\subsubsection{Superoxide Dismutase Scavenging Activity}

Both the metal chelates and APA were assessed against antioxidant activity [20]. The italicize of the ligand or its chelates to damped phenazine methosulphatemediated reduction of nitro blue tetrazolium dye was obtained from the results of 
the assay. The determination of SOD was calculated as reported earlier [18].

\subsubsection{Cell Cultures and Viability against HepG2}

The safety of HepG2 cells in culture was carried out in triplicate and calculated by the MTT assay as reported in our earlier work [21].

\subsection{Computational Details}

$\mathrm{DMOL}^{3}$ program [22] in materials studio package [23] was acquired for the data which is resolved for large-scale DFT calculations. DFT semi core pseudopods calculations were elicited with double numerical basis sets in addition to polarization functional. DNP basis sets are of comparable quality to 6-31G Gaussian basis sets [24]. The data acquired by DNP basis sets are more accurate than Gaussian basis sets of the same size as reported by Delley et al. [22]. The RPBE functional [25] is considered the best exchange-correlation function [26] establish on the generalized descended approximation (GGA) and is used to take account of the exchange and correlation impacts of electrons. Hence the geometric optimization is officiated without any symmetry curb.

\section{Results and Discussion}

Table 1 summarized the elemental analyses $(\mathrm{C}, \mathrm{H}, \mathrm{M}$, and $\mathrm{Cl})$ of the isolated metal chelates and some physical properties. The empirical formulae of the chelates are rimmed by elemental analyses $(\mathrm{C}, \mathrm{H}, \mathrm{N}, \mathrm{M}, \mathrm{Cl})$ and confirmed by thermal gravimetric data. The low values of molar conductance $\left(8-13 \mathrm{ohm}^{-1} \cdot \mathrm{cm}^{2} \cdot \mathrm{mol}^{-1}\right.$ range) of the chelates in DMSO (Table 1) suggest their non-electrolytic nature [27]. Doubtless, the lower $\mathrm{pH}$ of the solution during complex formation $(\mathrm{pH}=2$, 3, 2 and 5 for $\mathrm{Cu}^{2+}, \mathrm{Co}^{2+}, \mathrm{Pt}^{4+}$ and $\mathrm{Pd}^{2+}$, respectively) causes the block of the $\mathrm{NH}_{2}$ groups and consequently the enolization of the carbonyl group occurred with the liberation of a proton during complex formation. Hence, all the compounds were obtained by losing one or two protons as shown in Table 1 . The results

Table 1. Analytical and physical data of APA and its metal chelates.

\begin{tabular}{|c|c|c|c|c|c|c|c|c|c|}
\hline \multirow{2}{*}{$\begin{array}{l}\text { Compound; } \\
\text { (empirical formula) }\end{array}$} & \multirow{2}{*}{ (F. Wt) } & \multirow{2}{*}{ Color } & \multirow{2}{*}{$\begin{array}{l}\text { M.p. } \\
\left({ }^{\circ} \mathrm{C}\right)\end{array}$} & \multicolumn{4}{|c|}{ \% Found (Calcd.) } & \multirow{2}{*}{$\begin{array}{c}\mathrm{A}_{\mathrm{m}}^{+} \\
(\mathrm{DMSO})\end{array}$} & \multirow{2}{*}{$\begin{array}{c}\text { Yield } \\
(\%)\end{array}$} \\
\hline & & & & $\mathrm{C}$ & $\mathrm{H}$ & $\mathbf{M}$ & $\mathrm{Cl}$ & & \\
\hline APA; $\mathrm{C}_{10} \mathrm{H}_{10} \mathrm{~N}_{8} \mathrm{O}_{2}$ & 274.246 & Yellow & $156-157$ & $\begin{array}{c}44.6 \\
(43.8)\end{array}$ & $\begin{array}{c}4.6 \\
(3.7)\end{array}$ & --- & --- & --- & 70 \\
\hline $\begin{array}{l}{\left[\mathrm{Cu}_{2}(\text { APA-H })\left(\mathrm{H}_{2} \mathrm{O}\right) \mathrm{Cl}_{3}\right] \cdot \mathrm{H}_{2} \mathrm{O}} \\
\mathrm{C}_{10} \mathrm{H}_{13} \mathrm{Cu}_{2} \mathrm{~N}_{8} \mathrm{O}_{4} \mathrm{Cl}_{3}\end{array}$ & 542.721 & Brown & $>300$ & $\begin{array}{c}22.9 \\
(22.1)\end{array}$ & $\begin{array}{c}3.1 \\
(2.4)\end{array}$ & $\begin{array}{c}23.1 \\
(23.4)\end{array}$ & $\begin{array}{l}20.0 \\
(19.6)\end{array}$ & 9 & 83 \\
\hline $\begin{array}{l}{\left[\mathrm{Co}_{2}(\mathrm{APA}-2 \mathrm{H})\left(\mathrm{H}_{2} \mathrm{O}\right)_{2} \mathrm{Cl}_{2}\right] \cdot \mathrm{EtOH}} \\
\mathrm{C}_{12} \mathrm{H}_{18} \mathrm{Co}_{2} \mathrm{~N}_{8} \mathrm{O}_{5} \mathrm{Cl}_{2}\end{array}$ & 543.098 & Olive-green & $>300$ & $\begin{array}{l}26.01 \\
(26.5)\end{array}$ & $\begin{array}{c}4.2 \\
(3.3)\end{array}$ & $\begin{array}{l}20.96 \\
(21.7)\end{array}$ & $\begin{array}{c}13.7 \\
(13.1)\end{array}$ & 10 & 76 \\
\hline $\begin{array}{l}{\left[\mathrm{Pt}(\mathrm{APA}-\mathrm{H})\left(\mathrm{H}_{2} \mathrm{O}\right) \mathrm{Cl}_{3}\right] \cdot \mathrm{H}_{2} \mathrm{O} \cdot 2 \mathrm{EtOH}} \\
\mathrm{C}_{14} \mathrm{H}_{25} \mathrm{PtN}_{8} \mathrm{O}_{6} \mathrm{Cl}_{3}\end{array}$ & 702.849 & Light-brown & $>300$ & $\begin{array}{c}23.2 \\
(23.9)\end{array}$ & $\begin{array}{c}4.1 \\
(3.2)\end{array}$ & --- & $\begin{array}{c}16 \\
(15.1)\end{array}$ & 13 & 90 \\
\hline $\begin{array}{l}{\left[\mathrm{Pd}(\mathrm{APA}-\mathrm{H})\left(\mathrm{H}_{2} \mathrm{O}\right) \mathrm{C}\right] \cdot 2 / 1 \mathrm{EtOH}} \\
\mathrm{C}_{11} \mathrm{H}_{14} \mathrm{PdN}_{8} \mathrm{O}_{7 / 2} \mathrm{Cl}\end{array}$ & 456.162 & Olive-green & $>300$ & $\begin{array}{c}29.6 \\
(28.9)\end{array}$ & $\begin{array}{c}3.3 \\
(3.1)\end{array}$ & $\begin{array}{c}23.5 \\
(23.3)\end{array}$ & $\begin{array}{c}8.5 \\
(7.8)\end{array}$ & 8 & 69 \\
\hline
\end{tabular}


suggest that the comparatively high $\mathrm{pH}$ values of the $\mathrm{Co}^{2+}$ and $\mathrm{Pd}^{2+}(\mathrm{pH}=3$ and 5) complexes up stay for the liberations of two protons while the decline $\mathrm{pH}$ of $\mathrm{Cu}^{2+}$ and $\mathrm{Pt}^{4+}$ complexes give the chance to lose only one electron during the formation of the reactants.

\subsection{IR Spectra}

Two tautomer shapes [keto (a) and enol (b)] as elucidated in Figure 1(a), Figure 1(b) are suggested for APA on the basis of the results of IR spectra. The infrared spectrum of APA (KBr) shows three bands at 3416, 3306 and $3200 \mathrm{~cm}^{-1}$ imputable to $v(\mathrm{OH}), v_{a}\left(\mathrm{NH}_{2}\right)$ and $v_{s}\left(\mathrm{NH}_{2}\right)$ [28] vibrations, respectively. The band at 3150 $\mathrm{cm}^{-1}$ is attributed to $v\left(\mathrm{NH}_{2}\right)$ vibration [29]. The possibility of keto/enol tautomers $(\mathrm{HN}-\mathrm{C}=\mathrm{O} / \mathrm{N}=\mathrm{C}-\mathrm{OH})$ is reinforced by the observation of two $\mathrm{NH}$ group bands. The $v(\mathrm{C}=\mathrm{O}), v(\mathrm{C}=\mathrm{N})_{\text {azom. }}$. And $v(\mathrm{C}=\mathrm{N})$ vibrations of the pyrazine ring are observed at 1695, 1643 and $1562 \mathrm{~cm}^{-1}$, respectively [30] [31]. All these basics were ascertained and supported by studding the modeling of the ligand as shown in Figure 2.

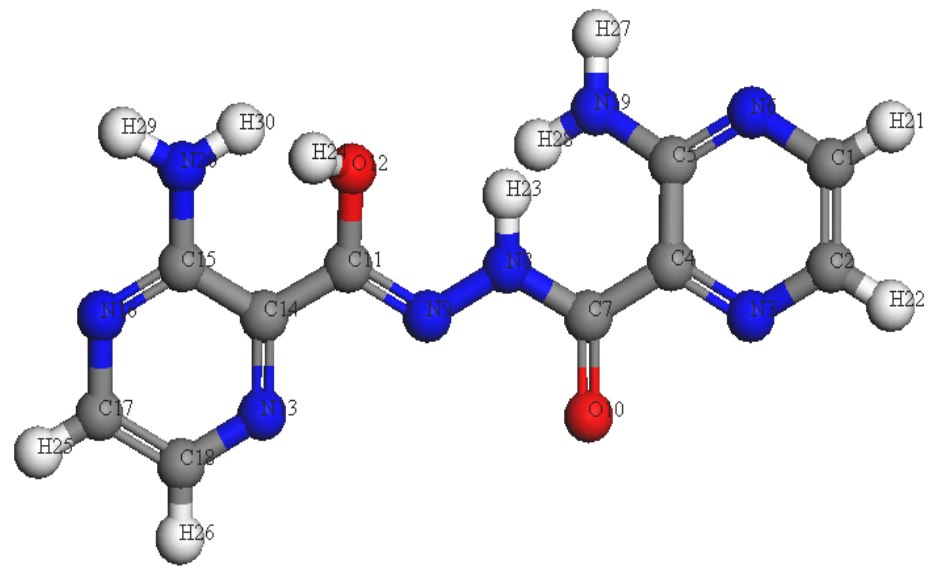

(a)

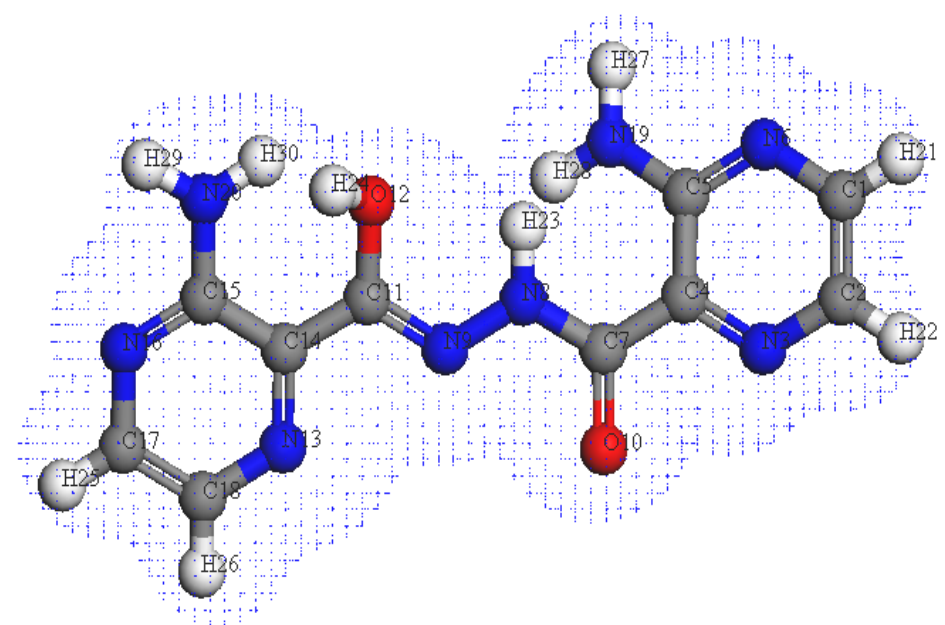

(b)

Figure 2. Molecular modeling of (a) APA (b) electron density. 
The infrared spectra of APA and the isolated metal chelates (Table 2) show that the ligand binds to $\mathrm{Cu}^{2+}$ and $\mathrm{Co}^{2+}$ metal ions in 2:1 (M:L) ratio and 1:1 in case of $\mathrm{Pt}^{4+}$ and $\mathrm{Pd}^{2+}$ metal ions. APA behaves as mononegative tetradentate coordinating via the two nitrogen of $\mathrm{NH}_{2}$ groups and two oxygen atoms with losing only one proton from the $\mathrm{OH}$ group (Figure 3) in case of $\mathrm{C}_{10} \mathrm{H}_{13} \mathrm{Cu}_{2} \mathrm{~N}_{8} \mathrm{O}_{4} \mathrm{Cl}_{3}$. The bonding sites are revealed by: 1) the $\mathrm{NH}_{2}$ and $\mathrm{C}=\mathrm{O}$ groups are relocated to lower wavenumbers indicating that these groups are participate in chelation; 2) the observation of new band at $1331 \mathrm{~cm}^{-1}$ attributed to (C-O) group; 3) new bands are traced at 532 and $467 \mathrm{~cm}^{-1}$ assigned to $\mathrm{M}-\mathrm{O}$ and $\mathrm{M}-\mathrm{N}$, respectively [32]. The spectrum of copper(II) chelate exhibits a broad band at $3416 \mathrm{~cm}^{-1}$ attributable to the water of coordination and water of solvation [33]. APA coordinates in a binegative tetradentate ligand via two $\mathrm{NH}_{2}$ groups and two oxygen atoms with losing two protons from the two $\mathrm{OH}$ groups in case of $\mathrm{Co}^{2+}$, with the general formulae, $\mathrm{C}_{12} \mathrm{H}_{18} \mathrm{Co}_{2} \mathrm{~N}_{8} \mathrm{O}_{5} \mathrm{Cl}_{2}$ (Figure 4). This conduct revealed by:

1) The hiding of the $(\mathrm{CO})$ group indicates this group is taking part in coordination after deprotonation.

2) The bands at $3285-3262 \mathrm{~cm}^{-1}$ attributable to $\left(\mathrm{NH}_{2}\right)$ are observed at lower wave numbers indicating that this group participates in bonding.

Table 2. The most important IR bands of APA and its metal chelates.

\begin{tabular}{|c|c|c|c|c|c|c|c|c|c|}
\hline Compound & $v(\mathrm{OH})$ & $v\left(\mathrm{NH}_{2}\right)$ & $v(\mathrm{NH})$ & $v(\mathrm{C}=\mathrm{O})$ & $v(\mathrm{C}=\mathrm{N})_{\mathrm{azo}}$ & $v(\mathrm{C}=\mathrm{N})_{\mathrm{pyrz}}$ & $v(\mathrm{C}-\mathrm{O})$ & $v(\mathrm{M}-\mathrm{O})$ & $v(\mathrm{M}-\mathrm{N})$ \\
\hline APA; $\mathrm{C}_{10} \mathrm{H}_{10} \mathrm{~N}_{8} \mathrm{O}_{2}$ & 3451 & $\begin{array}{l}(3381)_{\mathrm{as}} \\
(3313)_{\mathrm{s}}\end{array}$ & $\begin{array}{l}3187 \\
3152\end{array}$ & 1695 & 1643 & 1562 & --- & ---- & --- \\
\hline $\mathrm{C}_{10} \mathrm{H}_{13} \mathrm{Cu}_{2} \mathrm{~N}_{8} \mathrm{O}_{4} \mathrm{Cl}_{3}$ & 3416 & $\begin{array}{l}(3306)_{\mathrm{as}} \\
(3197)_{\mathrm{s}}\end{array}$ & 3150 & 1686 & 1650 & 1556 & 1331 & 532 & 467 \\
\hline $\mathrm{C}_{12} \mathrm{H}_{18} \mathrm{Co}_{2} \mathrm{~N}_{8} \mathrm{O}_{5} \mathrm{Cl}_{2}$ & 3401 & $\begin{array}{l}(3285)_{\mathrm{as}} \\
(3262)_{\mathrm{s}}\end{array}$ & --- & --- & $\begin{array}{l}1652 \\
1616\end{array}$ & 1556 & $\begin{array}{l}1335 \\
1315\end{array}$ & 536 & 464 \\
\hline $\mathrm{C}_{14} \mathrm{H}_{25} \mathrm{PtN}_{8} \mathrm{O}_{6} \mathrm{Cl}_{3}$ & 3405 & $\begin{array}{l}(3312)_{\mathrm{F}} \\
(3293)_{\mathrm{Ch}}\end{array}$ & 3150 & 1711 & 1614 & 1562 & 1317 & 544 & 473 \\
\hline $\mathrm{C}_{11} \mathrm{H}_{14} \mathrm{PdN}_{8} \mathrm{O}_{7 / 2} \mathrm{Cl}$ & 3422 & $\begin{array}{l}(3326)_{\mathrm{F}} \\
(3309)_{\mathrm{Ch}}\end{array}$ & 3145 & 1708 & 1622 & 1569 & 1323 & 494 & 461 \\
\hline
\end{tabular}

Note: azo: azomethine; pyrz: pyrazine ring.

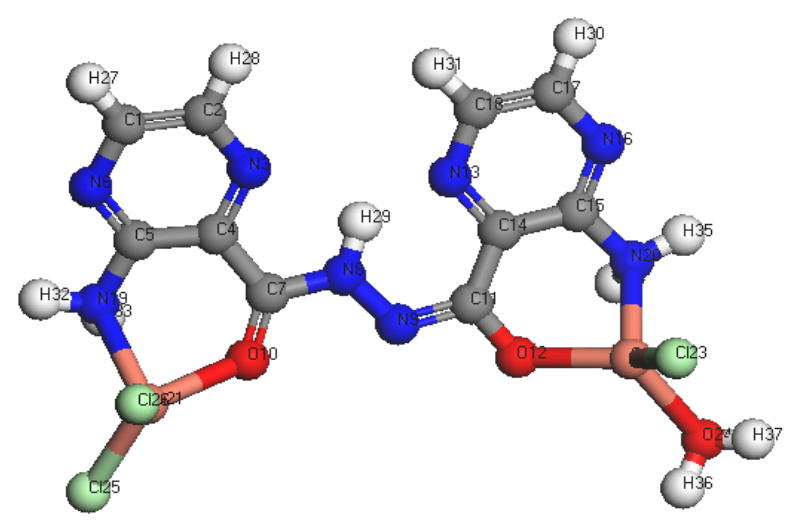

Figure 3. Molecular airing of $\mathrm{C}_{10} \mathrm{H}_{13} \mathrm{Cu}_{2} \mathrm{~N}_{8} \mathrm{O}_{4} \mathrm{Cl}_{3}$. 


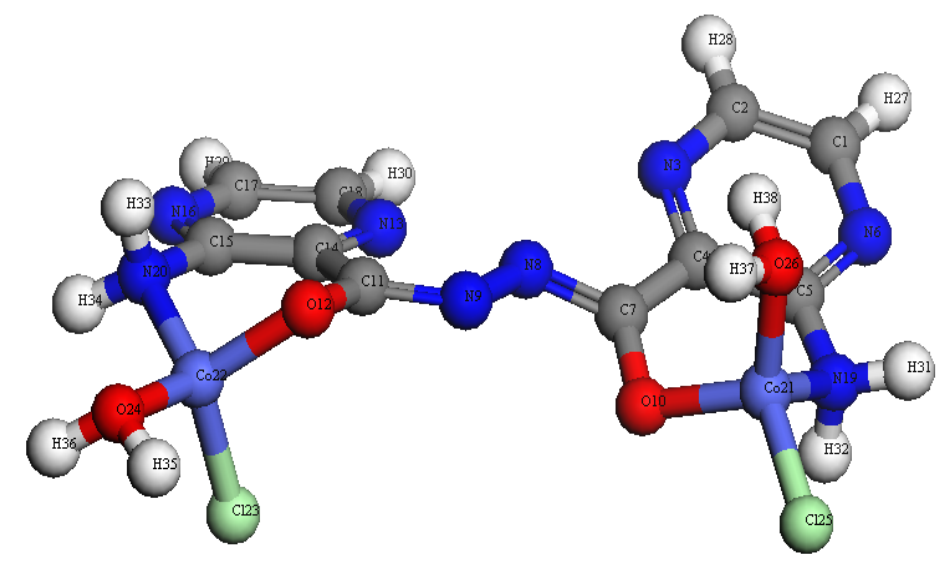

Figure 4. Molecular airing of $\mathrm{C}_{12} \mathrm{H}_{18} \mathrm{Co}_{2} \mathrm{~N}_{8} \mathrm{O}_{5} \mathrm{Cl}_{2}$.

3) The NH band is obscured with the simultaneous observation of a new band in the $1652-1616 \mathrm{~cm}^{-1}$ region assigned to the $(\mathrm{C}=\mathrm{N})_{\text {azom }}$, groups confirming the enolization of the $\mathrm{NH}$ groups together with the dislocation of a hydrogen atom from both $\mathrm{OH}$ groups.

4) Nouveau bands attributed to the (C-O) group are noticed in the $1553-1315$ $\mathrm{cm}^{-1}$ regions.

5) Nouveau bands at 536 and $464 \mathrm{~cm}^{-1}$ are attributed to $\mathrm{M}-\mathrm{O}$ and $\mathrm{M}-\mathrm{N}$ [32].

6) The chelates exhibit a broad band at $3401 \mathrm{~cm}^{-1}$ assignable to $\mathrm{H}_{2} \mathrm{O}$ and $\mathrm{EtOH}$ [33].

In the complexes, $\mathrm{C}_{14} \mathrm{H}_{25} \mathrm{PtN}_{8} \mathrm{O}_{6} \mathrm{Cl}_{3}$ and $\mathrm{C}_{11} \mathrm{H}_{14} \mathrm{PdN}_{8} \mathrm{O}_{7 / 2} \mathrm{Cl}$ (Figure 5, Figure 6), APA coordinates as a mononegative bidentate ligand through ( $\mathrm{N})$ of $\mathrm{NH}_{2}$ group and $(\mathrm{O})$ atom of deprotonated $\mathrm{C}-\mathrm{OH}$ group. The chelation is suggested by the displacement of the $\mathrm{NH}_{2}$ group to lower wavenumber together with the observation of new bands in the scale $1317-1323 \mathrm{~cm}^{-1}$ assigned to $v(\mathrm{C}-\mathrm{O})$ vibration. The medium broad band at 3405 and $3422 \mathrm{~cm}^{-1}$ are assigned to the coordinated water as well as ethanol [33]. Also, the bands observed in the range 544 494 and $473-461 \mathrm{~cm}^{-1}$ are assigned to M-O and M-N, respectively [32].

\subsection{Nuclear Magnetic Resonance Spectra ( ${ }^{1} \mathrm{H}-\mathrm{NMR}$ and $\left.{ }^{13} \mathrm{C}-\mathrm{NMR}\right)$}

Three signals at 9.8, 7.5 and $4.5 \mathrm{ppm}$, relative to TMS, are observed in the ${ }^{1} \mathrm{H}-\mathrm{NMR}$ spectrum of APA in $\mathrm{d}_{6}$-DMSO (Figure S1) and attributed to the protons of $\mathrm{OH}$ [34], $\mathrm{NH}$ and $\mathrm{NH}_{2}$ [28] groups and obscured on adding $\mathrm{D}_{2} \mathrm{O}$ (Figure S2). The protons of pyrazine ring are noticed in the (7.7 - 8.3) region ppm. The observation of the $\mathrm{OH}$ signal suggests that APA is existed in the keto/enol forms as illustrated in Figure 7. Additional backing for the composition of the ligand is attested from the arising of ten signals in the ${ }^{13} \mathrm{C}-\mathrm{NMR}$ spectrum (Figure 1) and the chemical shift of carbon $(\mathrm{C}=\mathrm{O})$ is observed at $167.02 \mathrm{ppm}$ [35]. The signals assigned to $\mathrm{C} 1, \mathrm{C} 2, \mathrm{C} 4$ and $\mathrm{C} 5$ are noticed at 155.3, 133.0, 123.7 and $156.4 \mathrm{ppm}$, respectively. The existences of $(\mathrm{OH})$ group adduced a great downfield shift of the (C14 and C18) and the up field shifts of $\mathrm{C} 11$ and $\mathrm{C} 15$ in accord with the 


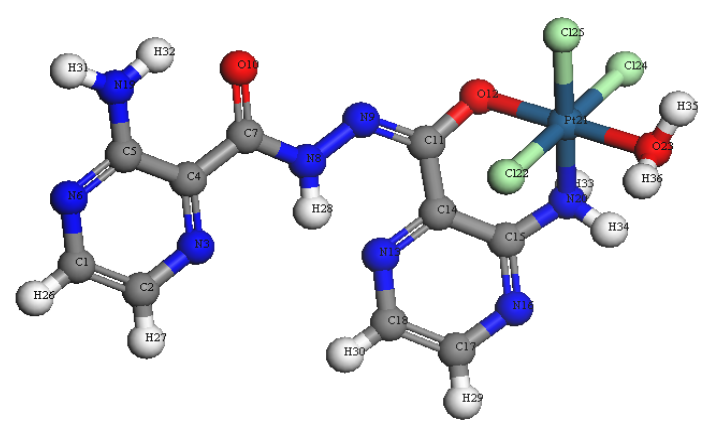

Figure 5. Molecular airing of $\mathrm{C}_{14} \mathrm{H}_{25} \mathrm{PtN}_{8} \mathrm{O}_{6} \mathrm{Cl}_{3}$.

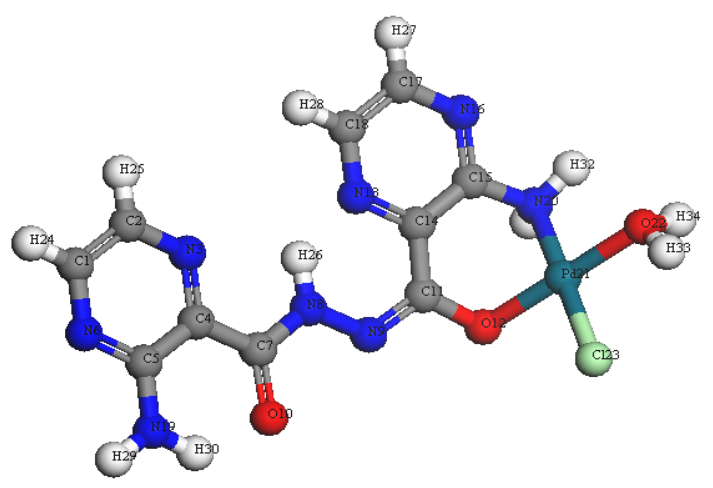

Figure 6. Molecular airing of $\mathrm{C}_{11} \mathrm{H}_{14} \mathrm{PdN}_{8} \mathrm{O}_{7 / 2} \mathrm{Cl}$.

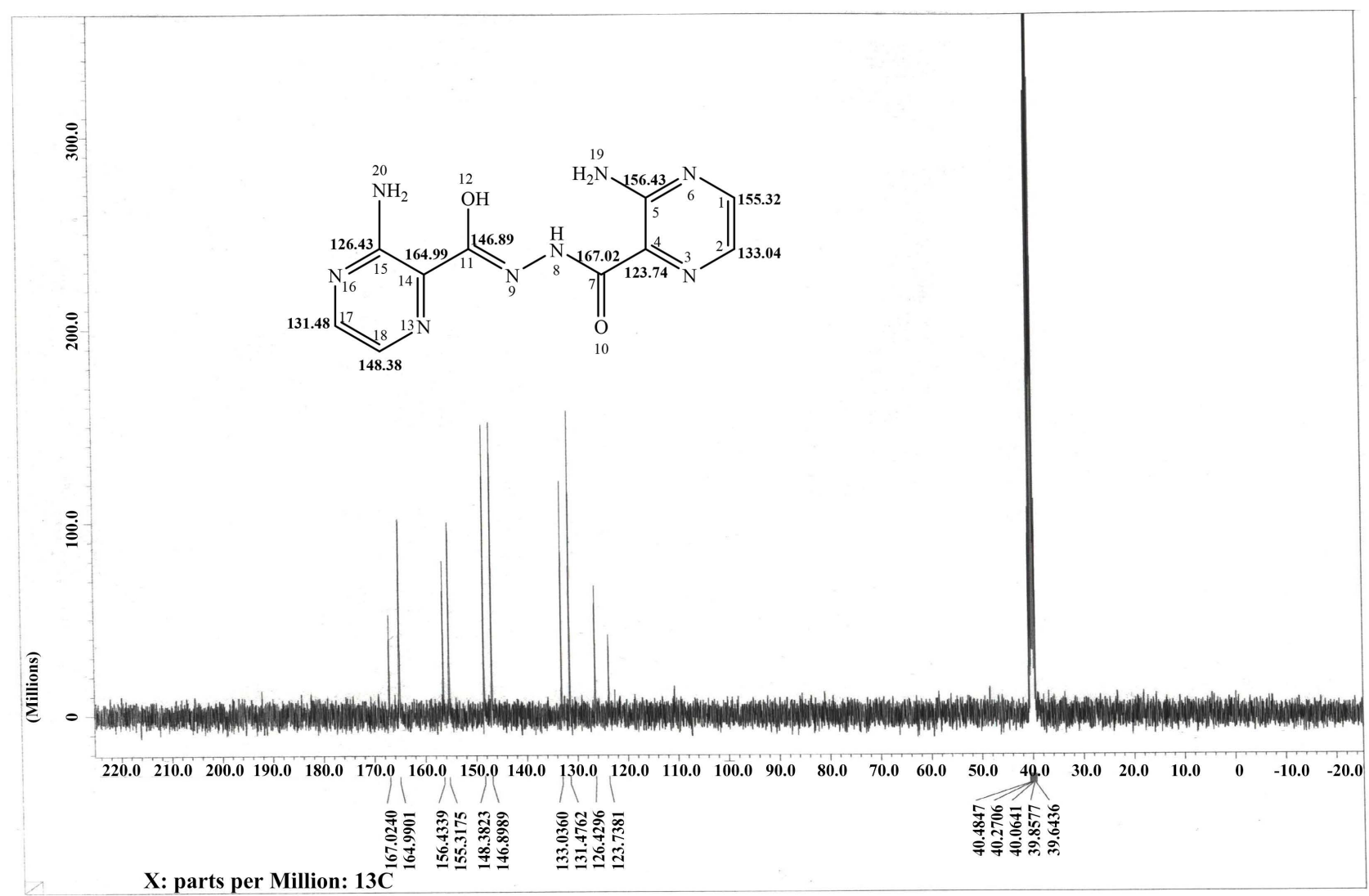

Figure $7 .{ }^{13} \mathrm{C}$-NMR spectrum of APA in $\mathrm{d}_{6}$-DMSO. 
trend of $\pi$-electron densities [36], which is taken as a strong guide that APA is existed in the keto/enol forms.

The ${ }^{1} \mathrm{H}-\mathrm{NMR}$ spectrum of $\mathrm{Pt}^{4+}$ chelate (Figure S3) shows signals at 9.01, 3.93 and $3.56 \mathrm{ppm}$ attributed to $\mathrm{NH}, \mathrm{NH}_{2}$ and $\mathrm{OH}\left(\mathrm{EtOH}\right.$ and $\left.\mathrm{H}_{2} \mathrm{O}\right)$ protons, respectively. The protons of pyrazine ring are noticed in the $8.55-7.96 \mathrm{ppm}$ range. The protons signal of ethanol $\left(\mathrm{CH}_{3}\right.$ and $\left.\mathrm{CH}_{2}\right)$ are observed at 1.35 and $4.38 \mathrm{ppm}$ indicating the existence of EtOH outside the coordination sphere [37]. The $\mathrm{Pd}^{2+}$ chelate spectrum (Figure S4) exhibits three signals at 8.27, 3.85 and $3.89 \mathrm{ppm}$ assigned to $\mathrm{NH}, \mathrm{NH}_{2}$ and $\mathrm{OH}\left(\mathrm{EtOH}\right.$ and $\left.\mathrm{H}_{2} \mathrm{O}\right)$ protons, respectively. The protons of the pyrazine ring are traced in the $7.98-7.59 \mathrm{ppm}$ range. The monitor of the proton signals of $\mathrm{CH}_{3}$ and $\mathrm{CH}_{2}(\mathrm{EtOH})$ outside the coordination sphere at 1.05 and 3.45 ppm verify the proposed formula [37].

\subsection{Mass Spectra}

Molecular ion peak noticed at $\mathrm{m} / \mathrm{z}=274(10 \%)$ corresponds to $\left(\mathrm{C}_{10} \mathrm{H}_{10} \mathrm{~N}_{8} \mathrm{O}_{2}\right), M$. wt. $=274.246$, as shown in the mass spectrum of APA (Figure 8). Elemental analyses and spectral are taken as strong brochure for the suggested geometry.

APA $\left(\mathrm{C}_{10} \mathrm{H}_{10} \mathrm{~N}_{8} \mathrm{O}_{2}\right)$ fragmentation pattern shows successive segments. The peak at $\mathrm{m} / \mathrm{z} 274.9$ (10\% abundance) represents the molecular ion (Calcd. 274.25). Also, the peak at 242 (46\% abundance) symbolizs to $\left[\mathrm{C}_{10} \mathrm{H}_{6} \mathrm{~N}_{6} \mathrm{O}_{2}\right]^{+}$(Calcd. 242.2) and the peak in 224 (48\% abundance) symbolizes to the fragment $\left[\mathrm{C}_{10} \mathrm{H}_{4} \mathrm{~N}_{6} \mathrm{O}\right]^{+}$. (Calcd. 224.2). The peak at 135 (100\% abundance) represents to $\left[\mathrm{C}_{5} \mathrm{H}_{2} \mathrm{~N}_{4} \mathrm{O}\right]^{+}$. (Calcd. 134.1) portions. The peak in 102 with $46 \%$ abundance corresponds to $\left[\mathrm{C}_{5} \mathrm{H}_{2} \mathrm{~N}_{2} \mathrm{O}\right]^{+}$(Calcd. 106.1). The molecular ion peaks in the mass spectrum of $\mathrm{C}_{12} \mathrm{H}_{18} \mathrm{Co}_{2} \mathrm{~N}_{8} \mathrm{O}_{5} \mathrm{Cl}_{2}$ approves with its formula. The mass spectrum of the $\mathrm{Co}^{2+}$ complex (Figure S5) elucidates the fragmentation example of the successive degradation of the chelate. The first peak at $\mathrm{m} / \mathrm{z} 543.2(0.02 \%$ abundance) represents the molecular ion (Calcd. 543.098). The peaks at 413, 299, 255, 199, 183, 153,

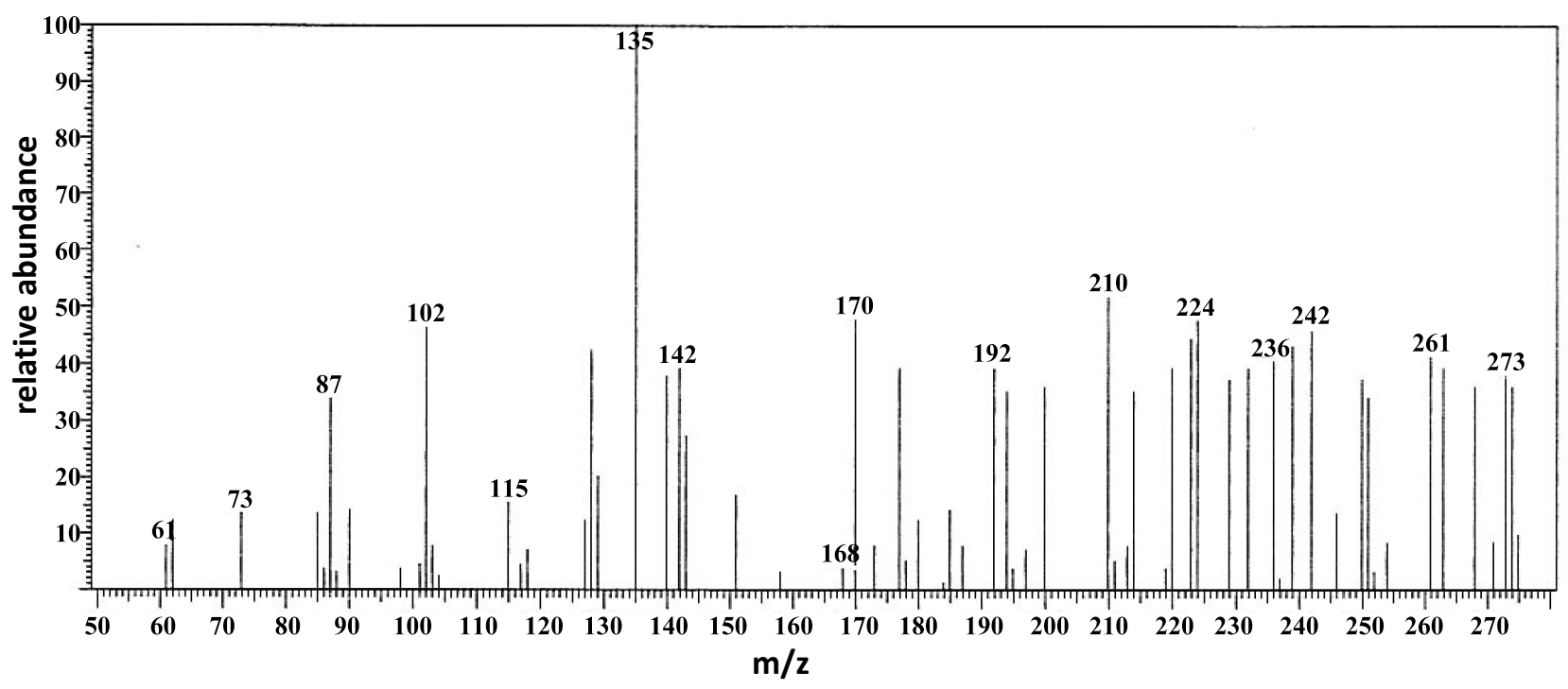

Figure 8. Mass spectrum of APA. 
96, 77 and 51 with 2, 23, 10, 24, 15, 53, 89, 46 and 100\% abundance (Calcd. 413.548, 301.149, 255.079, 199.054, 181.038, 153.027, 94.097, 78.074 and 51.048) correspond to $\left[\mathrm{C}_{8} \mathrm{H}_{14} \mathrm{Co}_{2} \mathrm{~N}_{5} \mathrm{O}_{5} \mathrm{Cl}\right]^{+},\left[\mathrm{C}_{8} \mathrm{H}_{12} \mathrm{CoN}_{5} \mathrm{O}_{4}\right]^{+},\left[\mathrm{C}_{6} \mathrm{H}_{6} \mathrm{CoN}_{5} \mathrm{O}_{3}\right]^{+},\left[\mathrm{C}_{5} \mathrm{H}_{6} \mathrm{Co}-\right.$ $\left.\mathrm{N}_{3} \mathrm{O}_{2}\right]^{+},\left[\mathrm{C}_{5} \mathrm{H}_{4} \mathrm{CoN}_{3} \mathrm{O}\right]^{+\cdot},\left[\mathrm{C}_{4} \mathrm{H}_{4} \mathrm{CoN}_{3}\right]^{+^{\cdot}},\left[\mathrm{C}_{4} \mathrm{H}_{4} \mathrm{~N}_{3}\right]^{+^{\cdot}},\left[\mathrm{C}_{4} \mathrm{H}_{2} \mathrm{~N}_{2}\right]^{+^{\cdot}}$ and $\left[\mathrm{C}_{3} \mathrm{HN}\right]^{+^{*}}$ parts, respectively. Also, the mass spectrum of $\mathrm{C}_{14} \mathrm{H}_{25} \mathrm{PtN}_{8} \mathrm{O}_{6} \mathrm{Cl}_{3}$ (Figure S6) shows a molecular ion peak at 702.6 which coincides with the theoretical value (702.849). The segment path of $\mathrm{C}_{14} \mathrm{H}_{25} \mathrm{PtN}_{8} \mathrm{O}_{6} \mathrm{Cl}_{3}$ is illustrated in Scheme $\mathrm{S} 1 . \mathrm{C}_{11} \mathrm{H}_{14} \mathrm{PdN}_{8} \mathrm{O}_{7 / 2} \mathrm{Cl}$ (Figure S7) exhibits a molecular ion peak equals 456 which is agreed with the calculated value (456.162) as illustrated from the mass spectrum. Scheme S2 depicts peaks corresponding to the successive degradation of $\mathrm{Pd}^{2+}$ chelate.

\subsection{Spectral and Magnetic Results}

All the electronic spectra of APA and its chelates were arises in Nujol mull. The chelates are distinctive by intense charge-transfer bands. The absorption band at $300-344 \mathrm{~nm}\left(33,333-28,901 \mathrm{~cm}^{-1}\right)$ is raised to $\pi \rightarrow \pi^{\star}$ transition of pyrazine rings are shown in the spectrum of APA. The absorption band observed at 402 $\mathrm{nm}\left(24,815 \mathrm{~cm}^{-1}\right)$ is assigned to $n \rightarrow \pi^{*}$ of the $\mathrm{NH}_{2}$ group, which shifts in chelates toward lower frequencies, supporting the chelation of the $\mathrm{NH}_{2}$ group in bonding. Another two bands appear at 452 and $548 \mathrm{~nm}\left(22,123\right.$ and 18,284 $\left.\mathrm{cm}^{-1}\right)$ are assigned to $\pi \rightarrow \pi^{*}$ of $(\mathrm{C}=\mathrm{N})_{\text {azom }}$ and $n \rightarrow \pi^{*}$ transitions of the carbonyl group, respectively [38] [39]. The ${ }^{2} B_{2} \rightarrow{ }^{2} E$ and ${ }^{2} B_{2} \rightarrow{ }^{2} B_{1}$ transitions at 728 and $574 \mathrm{~nm}$ $\left(13,736\right.$ and $\left.17,421 \mathrm{~cm}^{-1}\right)$ in the electronic spectrum of the $\mathrm{Cu}^{2+}$ chelate (Nujol) confirms the presence of tetrahedral structure around the $\mathrm{Cu}^{2+}$ ion [40]. The band at $525 \mathrm{~nm}\left(19,047 \mathrm{~cm}^{-1}\right)$ is attributed to type $L \rightarrow M$ transition. The corrected magnetic moment value $\left(\mu_{\text {eff }}=1.6 \mathrm{BM}\right)$ is calculated for each $\mathrm{Cu}^{2+}$ ion [41]. Also, the $\mathrm{Co}^{2+}$ chelate shows three bands at 691, 562 and $418 \mathrm{~nm}(14,471$, 17,793 and $\left.23,923 \mathrm{~cm}^{-1}\right)$. The first two bands are assigned to ${ }^{4} A_{2} \rightarrow{ }^{4} T_{1}(F)$ and ${ }^{4} A_{2} \rightarrow{ }^{4} T_{1}(P)$ transitions in a tetrahedral geometry around the $\mathrm{Co}^{2+}$ ion. The band at $23,923 \mathrm{~cm}^{-1}$ is raised to charge-transfer $(L \rightarrow M)$ [42]. The corrected magnetic moment $\left(\mu_{\text {eff }}=4.4 \mathrm{BM}\right)$ of $\mathrm{Co}^{2+}$ ion supports a tetrahedral geometry around the $\mathrm{Co}^{2+}[43]$. The values of to be $10 \mathrm{Dq}, \mathrm{B}$ and $\beta\left(519.9 \mathrm{~cm}^{-1}, 736.1\right.$ and 0.76), were calculated. $\mathrm{Pt}^{4+}$ chelate exhibits two bands at 486 and $440 \mathrm{~nm}(20,576$ and $22,727 \mathrm{~cm}^{-1}$ ) refers to the d-d transition bands ${ }^{1} A_{1 g} \rightarrow{ }^{1} T_{1 g}$ and ${ }^{1} A_{1 g} \rightarrow{ }^{1} T_{2 g}$, respectively [17]. Two bands at 388 and $592 \mathrm{~nm}\left(25,773\right.$ and $\left.16,891 \mathrm{~cm}^{-1}\right)$ assigned to ${ }^{1} A_{1 g} \rightarrow{ }^{1} B_{1 g}$ and ${ }^{1} A_{1 g} \rightarrow{ }^{1} E_{g}$ transitions in a square-planar configuration for the diamagnetic $\mathrm{C}_{11} \mathrm{H}_{14} \mathrm{PdN}_{8} \mathrm{O}_{7 / 2} \mathrm{Cl}$ [17] [44].

\subsection{Molecular Modeling}

\subsubsection{DFT Calculations for Optimization of the Geometry}

The optimization of APA and its metal chelates are displayed in Figures 2-6. The bond lengths and angles calculated by optimized molecular geometry are given in Tables S1-S10. The important points are summarized as follow:

1) On chelation the bond angles of APA are shifted; the most important effective changes are shown in $\mathrm{C}(15)-\mathrm{N}(20)-\mathrm{C}(14), \mathrm{C}(14)-\mathrm{C}(11)-\mathrm{O}(12), \mathrm{O}(12)-\mathrm{C}(11)$ - 
$\mathrm{N}(9), \mathrm{O}(10)-\mathrm{C}(7)-\mathrm{C}(4), \mathrm{N}(19)-\mathrm{C}(5)-\mathrm{C}(4)$ and $\mathrm{N}(8)-\mathrm{C}(7)-\mathrm{O}(10)$, which are affected (decrease or increase) on chelation due to chemical bonding [45].

2) Tetrahedral geometry of the $\mathrm{Cu}(\mathrm{II})$ and $\mathrm{Co}(\mathrm{II})$ chelates, $\mathrm{C}_{10} \mathrm{H}_{13} \mathrm{Cu}_{2} \mathrm{~N}_{8} \mathrm{O}_{4} \mathrm{Cl}_{3}$ and $\mathrm{C}_{12} \mathrm{H}_{18} \mathrm{Co}_{2} \mathrm{~N}_{8} \mathrm{O}_{5} \mathrm{Cl}_{2}$, is proposed on the basis of the values of bond angles, while octahedral geometry is propounded for $\mathrm{C}_{14} \mathrm{H}_{25} \mathrm{PtN}_{8} \mathrm{O}_{6} \mathrm{Cl}_{3}, 2 \mathrm{EtOH}$ and a square-planar for $\mathrm{C}_{11} \mathrm{H}_{14} \mathrm{PdN}_{8} \mathrm{O}_{7 / 2} \mathrm{Cl}$.

3) The metal chelates of APA are arraying according to M-O bond length as follows: $\mathrm{O}-\mathrm{Cu}>\mathrm{O}-\mathrm{Pt}>\mathrm{O}-\mathrm{Pd}>\mathrm{O}-\mathrm{Co}$.

4) According to M-N bond lengths the chelates of APA are arranged as follows: $\mathrm{N}-\mathrm{Cu}>\mathrm{N}-\mathrm{Pt}>\mathrm{N}-\mathrm{Pd}>\mathrm{N}-\mathrm{Co}$.

5) The angles around the metal centers undergo significant variations on changing the metal center while the bond angles in APA backbone do not change significantly.

\subsubsection{Chemical Reactivity}

\section{1) Methods of Describing the Global Reactivity}

The most important parameters in quantum calculations depend mainly on both the energies of the HOMO ( $\pi$-donor) and LUMO ( $\pi$-acceptor). These parameters are essentially behaved as an electron donor and electron acceptor, respectively, and these orbitals are known as Frontier Molecular Orbitals (FMOs).

1) The negative values of $E_{\text {номо }}$ and $E_{\text {LUмо }}$ and their neighboring orbitals (Table 3) anticipate the stability of the synthesized molecules [18].

2) The coordination sites (electrophilic attack) on aromatic compounds are easily anticipated using FMOs theory. The uttermost overlap between the HOMO on one molecule and the LUMO on the other illustrates that the reaction takes place. The most important factor in any reaction depends essentially on the interaction between HOMO and LUMO. The goal of the computations is to find out the highest values of molecular orbital coefficients. Consequently, the elevated value of molecular orbital coefficients for the ligand orbitals indicates its activity for chelation. All these keynotes are deduced from the data obtained

Table 3. Calculated Еномо, Elumo, energy band gap $\left(E_{\mathrm{H}}-E_{\mathrm{L}}\right)$, chemical potential $(\mu)$, electronegativity $(\chi)$, global hardness $(\eta)$, global softness $(S)$, global electrophilicity index $(\omega)$ and softness $(\sigma)$ for APA and its complexes.

\begin{tabular}{cccccccccc}
\hline Compound & $\begin{array}{c}E_{\mathrm{H}} \\
\mathrm{eV}\end{array}$ & $\begin{array}{c}E_{\mathrm{L}} \\
\mathrm{Ev}\end{array}$ & $\begin{array}{c}\left(E_{\mathrm{H}}-E_{\mathrm{L}}\right) \\
\mathrm{eV}\end{array}$ & $\begin{array}{c}\chi \\
\mathrm{eV}\end{array}$ & $\begin{array}{c}\mu \\
\mathrm{eV}\end{array}$ & $\begin{array}{c}H \\
\mathrm{Ev}\end{array}$ & $\begin{array}{c}S \\
\mathrm{eV}^{-1}\end{array}$ & $\begin{array}{c}\Omega \\
\mathrm{eV}\end{array}$ & $\begin{array}{c}\sigma \\
\mathrm{eV}\end{array}$ \\
\hline APA & -5.027 & -2.493 & -2.534 & 3.76 & -3.76 & 1.267 & 0.6335 & 8.95617 & 0.789266 \\
Cu complex & -5.199 & -3.265 & -1.934 & 4.232 & -4.232 & 0.967 & 0.4835 & 8.6594 & 1.034126 \\
Co complex & -4.485 & -3.632 & -0.853 & 4.0585 & -4.0585 & 0.4265 & 0.21325 & 3.512531 & 2.344666 \\
Pt complex & -5.516 & -4.034 & -1.482 & 4.775 & -4.775 & 0.741 & 0.3705 & 8.447632 & 1.349528 \\
Pd complex & -4.909 & -3.462 & -1.447 & 4.1855 & -4.1855 & 0.7235 & 0.36175 & 6.337285 & 1.38217 \\
\hline
\end{tabular}

$\mathrm{H}=\mathrm{HOMO}, \mathrm{L}=$ LUMO. 
from calculations indicating that the nitrogen of $\mathrm{NH}_{2}$ groups, oxygen of deprotonated $\mathrm{C}-\mathrm{OH}$ and carbonyl groups with largest values of molecular orbital coefficients.

3) Linert et al. [45] showed that the bond strength increases as the adjacent bonds become weaker according to Guttmann's variation rules. This view agrees with the results of increasing of the value of $\mathrm{E}_{\text {номо }}$ accompanying by elongation followed by the weakness of the metal-ligand bonds and the narrowness of the positions abutted to the metal-ligand centers and thus becomes quite strong.

4) The level of HOMO is essentially domestic on the $\mathrm{N}(20), \mathrm{N}(19)$ and $\mathrm{O}(10)$ and $\mathrm{O}(12)$ atoms (Figure 9) suggesting that these atoms are the most active nucleophile sites on the central metal ion. This indicates that these centers have high values of HOMO density coefficients and in face of the metal ions.

5) The energy gap ( $\left.\mathrm{E}_{\text {номо-}}-\mathrm{E}_{\mathrm{LUMO}}\right)[45]$ is used to calculate the kinetic stability and chemical reactivity of the APA. The theoretical model for illustrating the geometry and approval barriers in different modulate, which governs the biological bustle of the molecule, depends mainly on the energy gap. The softness of the molecule (more polarized) is known from the small gap. Accordingly, the reactivity of soft molecules than hard ones is mainly due to the easily offer electrons to an acceptor. The charge-transfer is easily occurred due to the small energy gap in case of APA suggests which effectuating the biological activity of the molecule. The groups that enter into conjugation causes the low value of energy gap.

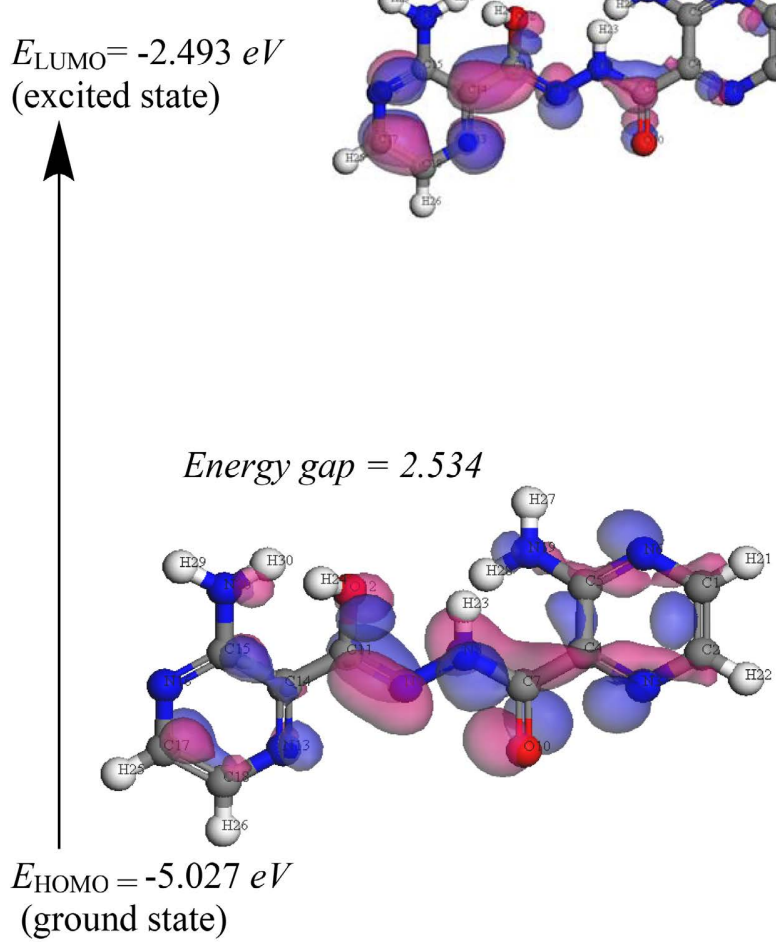

Figure 9. 3D plots frontier orbital energies using DFT method for APA. 
6) The donating electron capacity is weaker due to the lowering of the HOMO energy values. Contrarily, the molecule becomes good electron donor when the HOMO energy becomes higher. The ability of a molecule to receive electron depends on the LUMO energy [45].

Both the site selectivity and chemical reactivity of the molecular systems is figured out from DFT. The energies of both ( $\left.\mathrm{E}_{\text {номо }}+\mathrm{E}_{\mathrm{LUMO}}\right)$ and ( $\left.\mathrm{E}_{\text {номо }}-\mathrm{E}_{\mathrm{LUMO}}\right)$ construe the charge-transfer interaction, electronegativity $(\chi)$, chemical potential $(\mu)$, global hardness $(\eta)$, global softness $(S)$ and global electrophilicity index $(\omega)$ within the molecule [46] [47]. The results are depicted in Table 3.

$$
\begin{gathered}
\chi=-1 / 2\left(E_{\text {LUMO }}+E_{\text {номо }}\right) \\
\mu=-\chi=1 / 2\left(E_{\text {LUMO }}+E_{\text {Номо }}\right) \\
\eta=1 / 2\left(E_{\text {LUMO }}-E_{\text {номо }}\right) \\
S=1 / 2 \eta \\
\omega=\mu^{2} / 2 \eta
\end{gathered}
$$

The inverse value of the global hardness bestowed the softness $(\sigma)$ as follow:

$$
\sigma=1 / \eta
$$

The electrophilicity index is considered the most important quantum chemical factor which describes the toxicity of different pollutants in relation to their reactivity and site selectivity [48]. The biological activity of drug receptor interaction is illustrated from the value of electrophilicity. The new reactivity index is utilized to measure the stabilization energy when additional electronic charge from the environment from the system is needed. The measurements of the molecular stability and reactivity depend on the values of $\eta$ and $\sigma$. The metal ion acts as a Lewis acid while APA behaves as a Lewis base in chelate formation.

\subsubsection{Molecular Electrostatic Potential (MEP)}

The electrostatic potential mapped onto the constant electron density surface is obtained from the plot of MEP. Also, it is important in disquisition of the molecular structure with its physiochemical property nexus and hydrogen bonding interplay [49] [50] [51]. The values of $V(r)$ at $r(x, y$, and $z)$ is mooted in terms of the interaction energy between the electrical charge formed from the electrons of molecule, nuclei and proton located at $r$ [52] [53]. The plot of 3D of MEP for APA is labeled in Figure 10. The results showed that the maximum negative

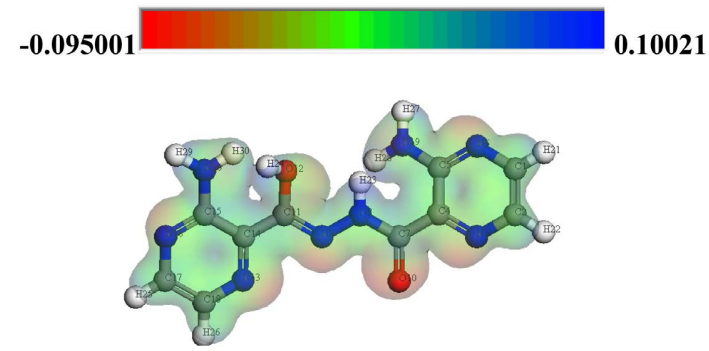

Figure 10. Molecular electrostatic potential of APA. 
region suggests the most suitable site for electrophilic attack which symbolized by a red color. The blue color represents the maximum positive region prefers site for nucleophile attack. Equivocally the increase of potential is in the order red $<$ green $<$ blue, where blue depicts the strongest attraction and red shows the strongest repulsion. The negative potential regions are existed over the more electronegative atoms meanwhile the regions with positive potential are found over the hydrogen atoms.

\subsubsection{Other Molecular Properties}

Binding energy estimations detect that the increase of the value of calculated binding energy of complexes in comparison to that of APA indicating that the stability of the formed metal chelate is higher than that of APA. DFT calculations conjecture this energy as shown in Table 4.

\subsection{Thermal Studies (TGA/DTG)}

The degradable stages, temperature ranges degradable products as well as the weight loss percentages of $\mathrm{Cu}^{2+}$ chelate are shown in Table S11. Also, Figure S8 illustrates the TGA/DTG curves of the chelate. The results suggest that the experimental weight loss agrees with the calculated values. The residue was confirmed by chemical analysis. The first stage at $32^{\circ} \mathrm{C}-102^{\circ} \mathrm{C}$ with weight loss of 3.3 (Calcd. 3.3\%) matches to the loss of $\mathrm{H}_{2} \mathrm{O}$ (lattice molecules) was shown from the TG thermogram of $\mathrm{C}_{10} \mathrm{H}_{13} \mathrm{Cu}_{2} \mathrm{~N}_{8} \mathrm{O}_{4} \mathrm{Cl}_{3}$. The weight loss of 27.1 (Calcd. 27.2\%) at $102^{\circ} \mathrm{C}-246^{\circ} \mathrm{C}$ is assigned to the loss of the coordination water molecules and $\left(\mathrm{C}_{4} \mathrm{H}_{4} \mathrm{~N}_{3}+\mathrm{Cl}\right)$ portions as shown from the second step. The removal of $\left(\mathrm{C}_{4} \mathrm{H}_{3} \mathrm{~N}_{3}\right)$ portions with weight loss of 17.1 (Calcd. $17.2 \%$ ) at $247^{\circ} \mathrm{C}-336^{\circ} \mathrm{C}$ is obtained from the third step. The fourth step at $336^{\circ} \mathrm{C}-416^{\circ} \mathrm{C}$ with weight wastage of 14.1 (Calcd. 13.4\%) indicates the removal of $2 \mathrm{HCl}$ molecules. Finally, the fifth step is noticed in the $417^{\circ} \mathrm{C}-569^{\circ} \mathrm{C}$ range with gradual mass loss corresponds to $\left(\mathrm{N}_{2}+\mathrm{C}\right.$ ) fragments, 7.3 (Calcd. $7.4 \%$ ). The final remainder is $\left[\mathrm{Cu}_{2}(\mathrm{O})_{2}\right]+\mathrm{C}$ (Found 31.1, Calcd. 31.5\%).

\subsection{Biological Studies}

\subsubsection{The Antioxidant Activity}

Antioxidant activity utilizing superoxide dismutase like activity assay was used

Table 4. Some of energetic properties of APA and its complexes calculated by $\mathrm{DMOL}^{3}$ using DFT-method.

\begin{tabular}{cccccc}
\hline Compound & $\begin{array}{c}\mathrm{HOMO} \\
(\mathrm{eV})\end{array}$ & $\begin{array}{c}\text { LOMO } \\
(\mathrm{eV})\end{array}$ & $\begin{array}{c}\text { Binding energy } \\
(\mathrm{Kcal} / \mathrm{mol})\end{array}$ & $\begin{array}{c}\text { Total energy } \\
(\mathrm{Kcal} / \mathrm{mol})\end{array}$ & $\begin{array}{c}\text { Dipole moment } \\
(\mathrm{D})\end{array}$ \\
\hline $\mathrm{APA}$ & -5.027 & -2.493 & -3368.8 & $-6.1 \times 10^{5}$ & 6.9624 \\
$\mathrm{C}_{10} \mathrm{H}_{13} \mathrm{Cu}_{2} \mathrm{~N}_{8} \mathrm{O}_{4} \mathrm{Cl}_{3}$ & -5.199 & -3.265 & -4185.1 & $-1.8 \times 10^{6}$ & 6.6597 \\
$\mathrm{C}_{12} \mathrm{H}_{18} \mathrm{Co}_{2} \mathrm{~N}_{8} \mathrm{O}_{5} \mathrm{Cl}_{2}$ & -4.485 & -3.632 & -4043.2 & $-1.4 \times 10^{6}$ & 5.0550 \\
$\mathrm{C}_{14} \mathrm{H}_{25} \mathrm{PtN}_{8} \mathrm{O}_{6} \mathrm{Cl}_{3}$ & -5.516 & -4.034 & -3756.7 & $-1.6 \times 10^{6}$ & 8.9002 \\
$\mathrm{C}_{11} \mathrm{H}_{14} \mathrm{PdN}_{8} \mathrm{O}_{7 / 2} \mathrm{Cl}$ & -4.909 & -3.462 & -3619.9 & $-1.0 \times 10^{6}$ & 7.6981 \\
\hline
\end{tabular}


to check out all the chelates. In contrarily, the $\mathrm{Pd}^{2+}$ chelate shows no antioxidant activity while APA showed from low to mediate anti-oxidative activity as shown in Figure 11.

The $\mathrm{Cu}^{2+}, \mathrm{Co}^{2+}$ and $\mathrm{Pt}^{4+}$ chelates have the highest activity of quenching phenazin methosulphate radicals at $76.3 \%, 83.0 \%$ and $88.1 \%$ inhibition, respectively. The high potency of antioxidant is due to the fared of chelation. This is due to structure-activity relationship: they differ in the coordination geometries and stability and distortion. Moreover, the difference in the dipole moment of the complexes affects the stability, the distortion and the activity of the complexes. The compounds under investigation are considered as important group of promising antioxidants and also help to attenuate oxidative stress and used in protection against the harmful action of reactive oxygen species, mainly oxygen free radicals.

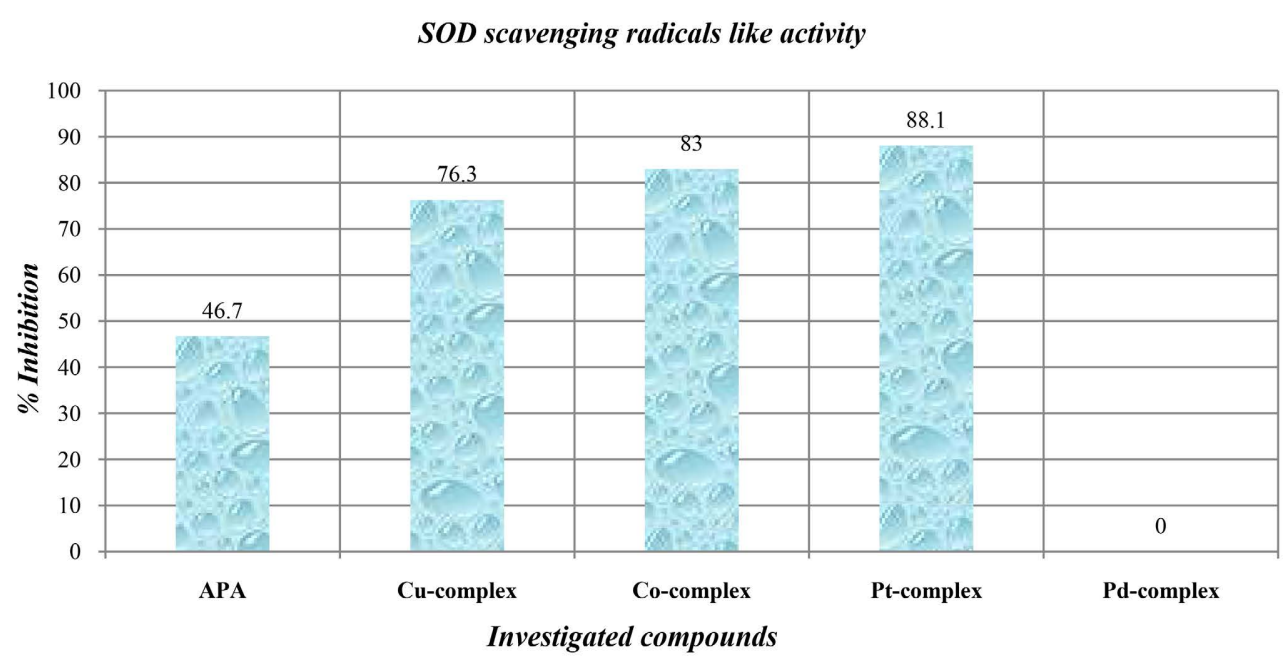

Figure 11. Superoxide dismutase scavenging radicals like activity of APA and its chelates.

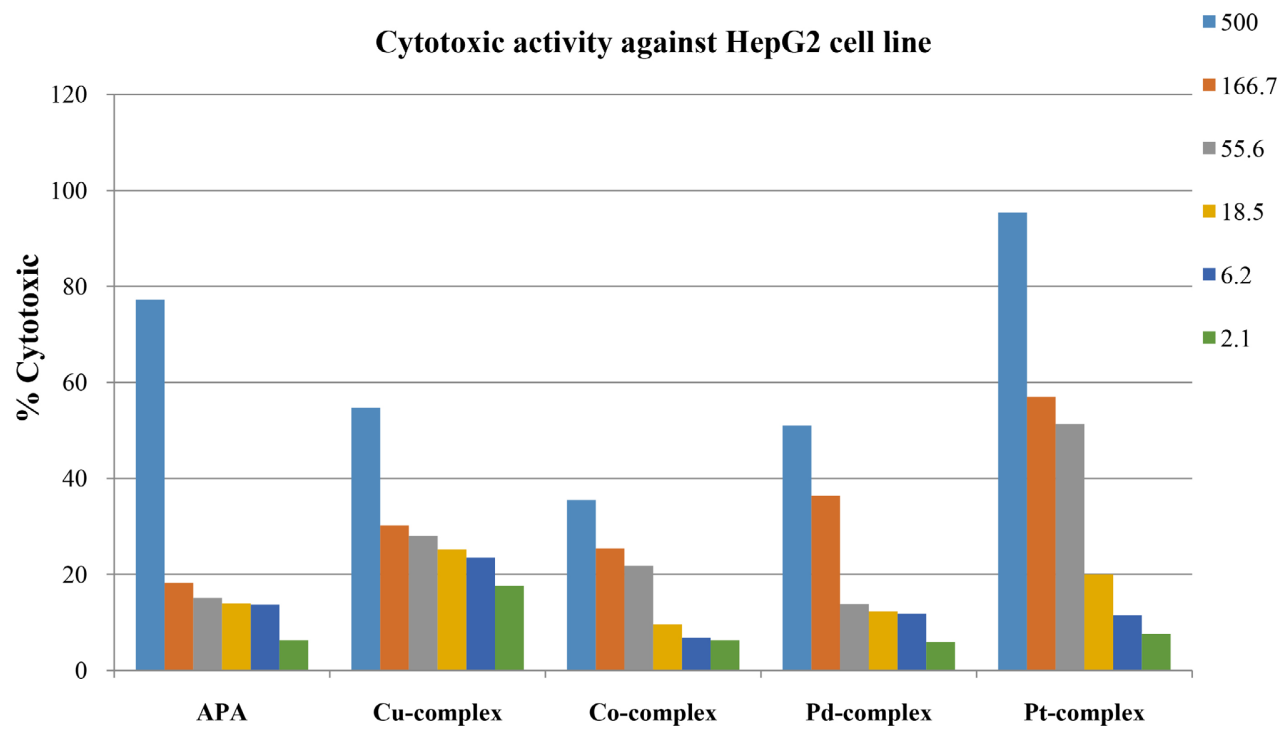

Figure 12. Cytotoxic activity of APA and its chelates. 


\subsubsection{Cytotoxic and Antitumor Activity}

APA and its metal chelates were tried against hepatocellular carcinoma cell line HepG2 for their antitumor activity (Figure 12). After few days' incubation of the HepG2 liver cancer cells using different concentrations of APA and its chelates, $\mathrm{Pt}^{4+}$ proved to have the highest cytotoxic activity with $\mathrm{IC}_{50}$ of $79.8 \mu \mathrm{M}$.

The viability of HepG2 tumor cells after incubation with $\mathrm{Pt}^{4+}$ chelate is highly affected. The cell layer partially condensed forming cell-free areas and finally detached from the culture plate. APA and its chelates $\left(\mathrm{Cu}^{2+}, \mathrm{Co}^{2+}\right.$ and $\left.\mathrm{Pd}^{2+}\right)$ show no significant cytotoxic activity. The data indicate that there is no significant difference in cell death in comparison to the untreated control (negative control).

\section{Conclusion}

Metal chelates $\left(\mathrm{Cu}^{2+}, \mathrm{Co}^{2+}, \mathrm{Pt}^{4+}\right.$ and $\left.\mathrm{Pd}^{2+}\right)$ derived from the novel ligand, (Z)-3amino-N-(3-aminopyrazine-2-carbonyl) pyrazine-2-carbohydrazonic acid (APA, L) were synthesized and achieved by conventional physical and chemical, spectroscopic, magnetic and TGA studies. APA behaves in tridentate and tetradentate manners as in the case of $\mathrm{Cu}^{2+}$ and $\mathrm{Co}^{2+}$, respectively. Also, the ligand acts in a bidentate manner towards $\mathrm{Pt}^{4+}$ and $\mathrm{Pd}^{2+}$ chelates. Both the corrected $\mu_{\text {eff. }}$ and spectral data propose the geometries of the chelates and the molecular modeling. The chemical activity, energy components and also MEP for APA are figured out. In Vitro, cytotoxic activity and superoxide dismutase radical scavenger-like activity of the synthesized compounds HepG2 liver cancer cells were examined. Metal chelates show the potent anti-oxidative activity. The results of cytotoxic activity assay against hepatocellular carcinoma cell line HepG2 confirmed that $\mathrm{Pt}^{4+}$ complex has the highest value, while $\mathrm{APA}, \mathrm{Cu}^{2+}, \mathrm{Co}^{2+}$ and $\mathrm{Pd}^{2+}$ chelates have no significant cytotoxic activity.

\section{Conflicts of Interest}

The authors declare that they have no conflict of interests that could influence this work.

\section{References}

[1] Kerru, N., Gummidi, L., Maddila, S., Gangu, K.K. and Jonnalagadda, S.B. (2020) A Review on Recent Advances in Nitrogen-Containing Molecules and Their Biological Applications. Molecules, 25, 1909-1951. https://doi.org/10.3390/molecules25081909

[2] Jampilek, J. (2019) Heterocycles in Medicinal Chemistry. Molecules, 24, 3839-3842. https://doi.org/10.3390/molecules24213839

[3] Hosseinzadeh, Z., Ramazani, A. and Razzaghi-Asl, N. (2018) Anti-Cancer NitrogenContaining Heterocyclic Compounds. Current Organic Chemistry, 23, 2256-2279. https://doi.org/10.2174/1385272822666181008142138

[4] Shetty, N and Gupta, S. (2014) Eribulin Drug Review. South Asian Journal of Cancer, 3, 57-59. https://doi.org/10.4103/2278-330X.126527

[5] Welsh, S and Corrie, P (2015) Management of BRAF and MEK Inhibitor Toxicities in Patients with Metastatic Melanoma. Therapeutic Advances in Medical Oncology, 


\section{7, 122-136. https://doi.org/10.1177/1758834014566428}

[6] Kakkar, S., Kumar, S., Narasimhan1, B., Lim, S.M, Ramasamy, K. Mani, V. and Shah, S.A.A. (2018) Design, Synthesis and Biological Potential of Heterocyclic Benzoxazole Scaffolds as Promising Antimicrobial and Anticancer Agents. Chemistry Central Journal, 96, Article No. 96. https://doi.org/10.1186/s13065-018-0464-8

[7] Schneider, M.R. (1987) Hydroxy Substituted 10-Ethyl-9-phenylphenanthrenes: Compounds for the Investigation of the Influence of E, Z-Isomerization on the Biological Properties of Tumor Inhibiting 1.1.2-Triphenylbutenes. Archiv der Pharmazie, 320, 159-166. https://doi.org/10.1002/ardp.19873200212

[8] Nawrocka, W. and Stasko, J. (1997) New Derivatives of 3Amino-2(1H)-Thioxo4(3H)-Quinazolinone. Part II. Reaction of 3-Amino-2(1H)-Thioxo-4(3H)-Quinazolinone with Cyanogen Bromide. Polish Journal of Chemistry, 71, 792-796.

[9] Nawrocka, W., Sztuba, B., Drys, A., Wietrzyk, J., Kosendiak, J. and Opolski, A. (2014) Synthesis and AntiProliferative Activity in vitro of New 2-Aminobenzimidazole Derivatives. Reaction of 2-Arylideneaminobenzimidazole with Selected Nitriles Containing Active Methylene Group. Central European Journal of Chemistry, 12, $1047-$ 1055. https://doi.org/10.2478/s11532-014-0533-3

[10] Milczarska, B., Gobis, K., Foks, H., Golunski, L.L. and Sowinski, P. (2012) The Synthesis of 3-Amino-Pyrazine-2-Carbohydrazide and 3-Amino-N'-Methylpyrazine2-Carbohydrazide Derivatives. Heterocyclic Chemistry, 49, 845-850. https://doi.org/10.1002/jhet.877

[11] Bergman, J. and Brynolf, A. (1990) Synthesis of Chrysogine, a Metabolite of Penicillium chrysogenum and Some Related 2-Substituted 4- $(3 \mathrm{H})$-Quinazolinones. Tetrahedron, 46, 1295-1310. https://doi.org/10.1016/S0040-4020(01)86694-1

[12] Jakobsen, P., Horneman, A.M. and Persson, E. (2000) Inhibitors of the Tissue Factor/Factor VIIa-Induced Coagulation: Synthesis and in Vitro Evaluation of Novel 2-Aryl Substituted Pyrid. Bioorganic \& Medicinal Chemistry, 8, 2803-2812.

[13] Maga, J.A. (1992) Pyrazine Update. Food Reviews International, 8, 479-558. https://doi.org/10.1080/87559129209540951

[14] Yamaguchi, T., Ito, S., Kashige, N., Nakahara, K. and Harano, K. (2007) The Relationship between the Chemical Structures of Dihydropyrazine Derivatives and DNA Strand-Breakage Activity. Chemical and Pharmaceutical Bulletin, 55, 532-536. https://doi.org/10.1248/cpb.55.532

[15] Dolezal, M. (2006) Biologically Active Pyrazines of Natural and Synthetic Origin. Chemické Listy, 100, 959-966.

[16] Vogel, A.I. (1961) A Text Book of Quantitative Inorganic Analysis. Longmans, London.

[17] Bain, G.A. and John, F. (2008) Diamagnetic Corrections and Pascal's Constant. Journal of Chemical Education, 85, 532-536. https://doi.org/10.1021/ed085p532

[18] Nishikimi, M., Appaji, N. and Yagi, K. (1972) The Occurrence of Superoxide Anion in the Reaction of Reduced Phenazine Methosulfate and Molecular Oxygen. Biochemical and Biophysical Research Communications, 46, 849-854. https://doi.org/10.1016/S0006-291X(72)80218-3

[19] Selvakumaran, M., (2003) Enhanced Cisplatin Cytotoxicity by Disturbing the Nucleotide Excision Repair Pathway in Ovarian Cancer Cell Line. Cancer Research, 63, 1311-3116.

[20] Delley, B. (1990) An All-Electron Numerical Method for Solving the Local Density Functional or Pyatomic Molecules. Journal of Chemical Physics, 92, 508-517. https://doi.org/10.1063/1.458452 
[21] Materials Studio 6.0 Copyright (2009) Accelrys Software Inc.

[22] Hehre, W.J., Radom, L., Schleyer, P.V.R. and Pople, J.A. (1986) Ab Initio Molecular Orbital Theory. John Wiley \& Sons, New York.

[23] Hammer, B., Hansen, L.B. and Nørskov, J.K. (1999) Improved Adsorption Energetics within Density-Functional Theory Using Revised Perdew-Burke-Ernzerh of functionals. Physical Review B, 59, 7413-7421. https://doi.org/10.1103/PhysRevB.59.7413

[24] Matveev, A., Staufer, M., Mayer, M. and Roesch, N. (1999) Density Functional Study of Small Molecules and Transition-Metal Carbonyls Using Revised PBE Functional. International Journal of Quantum Chemistry, 75, 863-873. https://doi.org/10.1002/(SICI)1097-461X(1999)75:4/5<863::AID-QUA51>3.0.CO;2-T

[25] Geary, W.J. (1971) The Use of Conductivity Measurements in Organic Solvents for the Characterization of Coordination Compounds. Coordination Chemistry Reviews, 7, 81-122. https://doi.org/10.1016/S0010-8545(00)80009-0

[26] Ketcham, K.A., Garcia, I., Swearingen, J.K., El-Sawaf, A.K., Bermejo, E., Castineiras, A. and West, D.X. (2002) Spectral Studies and X-Ray Crystal Structures of Three Nickel(II) Complexes of 2-Pyridineformamide 3-Piperidylthiosemicarbazon. Polyhedron, 21, 859-865. https://doi.org/10.1016/S0277-5387(02)00853-7

[27] Salah, S., El-Wahab, A., Zeinab, H., Farag, R.S. and Mostafa, M.M. (2014) Synthesis, Characterization and Modeling Structures of Isatin-3-Girard T (IGT) and P (IGP) Hydrazone Complexes. Spectrochimica Acta, 124, 579-587. https://doi.org/10.1016/j.saa.2014.01.082

[28] Alpert, N.L., Keiser, W.E. and Szmanski, H.A. (1970) IR Theory and Practice of Infrared Spectroscopy, Plenum Press, New York. https://doi.org/10.1007/978-1-4684-8160-0_1

[29] Azhari, S.J., Mlahi, M.R., Al-Asmy, A.A. and Mostafa, M.M. (2015) Synthesis of Novel Binary and Ternary Complexes Derived from 1-(2-Hydroxybenzoyl)-4-Phenylthiosemicarbazide $\left(\mathrm{L}^{1}\right)$ and 2,2'-Dipyridyl $\left(\mathrm{L}^{2}\right)$ with $\mathrm{Co}^{\mathrm{II}}, \mathrm{Cu}^{\mathrm{II}}$ and $\mathrm{Zn}^{\mathrm{II}}$ Salts. Spectrochimica Acta, 36, 185-191. https://doi.org/10.1016/j.saa.2014.09.012

[30] Nakamoto, K. (2009) Infrared and Raman Spectra of Inorganic and Coordination Compounds. 6th Edition, John Wiley and Sons, Inc., Hoboken.

https://doi.org/10.1002/9780470405840

[31] Ferraro, J.R. and Walker, W.R. (1965) Infrared Spectra of Hydroxy-Bridged Copper(II) Compounds. Inorganic Chemistry, 4, 1382-1386. https://doi.org/10.1021/ic50032a002

[32] Rageovic, K.C., Kakurinov, V.V., Molnar, D.G. and Buzarovska, A. (2001) Synthesis, Antibacterial and Antifungal Activity of 4-Substituted-5-Aryl-1,2,4-Triazoles. Molecules, 6, 815-824. https://doi.org/10.3390/61000815

[33] Ramachandran, R., Rani, M. and Kabilan, S.J. (2010) Synthesis, Structure and Conformational Analysis of 2,4-diaryl-3-azabicyclo[3.3.1]nonan-9-one Thiosemicarbazones and Semicarbazones. Journal of Molecular Structure, 970, 42-50. https://doi.org/10.1016/j.molstruc.2010.02.005

[34] Kidrič, J., Hadži, D., Kocjan, D. and Rutar, V. (1981) ${ }^{1} \mathrm{H}$ and ${ }^{13} \mathrm{C}$ NMR Study of 8-Hydroxyquinoline and Some of Its 5-Substituted Analogues. Organic Magnetic Resonance, 15, 280-284. https://doi.org/10.1002/mrc.1270150314

[35] Silverstein R.M. and Bassler, G.C. (1967) Spectroscopic Identification of Organic Compounds. Wiley, New York.

[36] Tossidis, I.A., Bolos, C.A., Aslinidis, P.N. and Katsoulos, G.A. (1987) Monohaloge- 
nobenzoylhydrazones III. Synthesis and Structural Studies of $\mathrm{Pt}(\mathrm{II}), \mathrm{Pd}(\mathrm{II})$ and $\mathrm{Rh}(\mathrm{III})$ Complexes of Di-(Pyridyl)Ketonechlorobenzoyl Hydrazones. Inorganica Chimica Acta, 133, 275-280. https://doi.org/10.1016/S0020-1693(00)87779-8

[37] Rao, C.N.R. (1975) Ultraviolet and Visible Spectroscopy. Plenum Press, New York.

[38] Lever, A.B.P. (1968) Inorganic Electronic Spectroscopy. Elsevier, Amsterdam.

[39] Kato, M., Jonassen, K.B. and Fanning, G.C. (1964) Copper(II) Complexes with Subnormal Magnetic Moments. Chemical Reviews, 64, 99-128. https://doi.org/10.1021/cr60228a003

[40] Kettle, S.F.A. (1969) Coordination Compounds. Thomas Nelson and Sons Let, London.

[41] Lewis, J. and Wilkins, R.G. (1960) Modern Coordination Chemistry. Interscince, New York.

[42] Al-assy, W.H., El-askalany, A.H. and Mostafa, M.M. (2013) Structural Comparative Studies on New $\mathrm{Mn}(\mathrm{II}), \mathrm{Cr}(\mathrm{III})$ and $\mathrm{Ru}(\mathrm{III})$ Complexes Derived from 2,4,6-Tri(2-Pyridyl)-1,3,5-Triazine (TPTZ) Spectrochimica Acta, 116, 401-407. https://doi.org/10.1016/j.saa.2013.07.086

[43] Yousef, T.A., El-Reash, G.M.A. and El Morshedy, R.M. (2012) Quantum Chemical Calculations, Experimental Investigations and DNA Studies on (E)2-((3-Hydroxy-Naphthalen-2-yl) Methylene)-N-(Pyridin-2-yl) Hydrazine Carbothioamide and Its $\mathrm{Mn}(\mathrm{II}), \mathrm{Ni}(\mathrm{II}), \mathrm{Cu}(\mathrm{II}), \mathrm{Zn}(\mathrm{II})$ and $\mathrm{Cd}(\mathrm{II})$ Complexes. Polyhedron, 45, 71-85. https://doi.org/10.1016/j.poly.2012.07.041

[44] Linert, W. and Taha, A. (1994) Co-ordination of Solvent Molecules to Square-Planar Mixed-Ligand Nickel(II) Complexes. A Thermodynamic and Quantum-Mechanical Study. Journal of the Chemical Society, Dalton Transactions, 7, 1091-1095. https://doi.org/10.1039/dt9940001091

[45] Govindarajan, M., Periandy, S. and Carthigayen, K. (2012) FT-IR and FT-Raman Spectra, Thermodynamical Behavior, HOMO and LUMO, UV, NLO Properties, Computed Frequency Estimation Analysis and Electronic Structure Calculations on a-Bromotoluene. Spectrochimica Acta, 97, 41-422. https://doi.org/10.1016/j.saa.2012.06.028

[46] Pearson, R.G. (1989) Estimating Vorization Enthalpies of Organic Compounds with Single and Multiple Substitution. The Journal of Organic Chemistry, 54, 5250-5256. https://doi.org/10.1021/jo00283a016

[47] Padmanabhan, J., Parthasarathi, R., Subramanian, V. and Chattaraj, P. (2007) Density Functional Tanalysis of Molybdenum Isotope Fractionation. The Journal of Physical Chemistry A, 111, 12434-12438. https://doi.org/10.1021/jp074318q

[48] Parthasarathi, R., Padmanabhan, J., Sarkar, U., Maiti, B., Subramanian, V. and Chattaraj, P.K. (2003) Toxicity Analysis of Benzidine through Chemical Reactivity and Selectivity Profiles: A DFT Approach. Internet Electronic Journal of Molecular Design, 2, 798-813.

[49] Scrocco, E. and Tomasi, J. (1978) Electronic Molecular Structure, Advances in Quantum Chemistry. Academic Press, Cambridge, MA.

[50] Luque, F.J., López, J.M. and Orozco, M. (2000) Perspective on "Electrostatic Interactions of a Solute with a Continuum. A Direct Utilization of $A b$ initio Molecular Potentials for the Prevision of Solvent Effects". Theoretical Chemistry Accounts, 103, 343-345. https://doi.org/10.1007/s002149900013

[51] Okulik, N. and Ubert, A.H.J. (2005) Theoretical Analysis of the Reactivity Sites of Non-Inflammatory Drugs. Internet Electronic Journal of Molecular Design, 4, 
17-30.

[52] Politzer, P., Laurence, P.R. and Jayasuriya, K. (1985) Molecular Electrostatic Potentials: An Effective Tool for the Elucidation of Biochemical Phenomena. Environmental Health Perspectives, 61, 191-202. https://doi.org/10.1289/ehp.8561191

[53] Scrocco, E. and Tomasi, J. (1973) The Electrostatic Molecular Potential as a Tool for the Interpretation of Molecular Properties. In: New Concepts II, Topics in Current Chemistry Fortschritte der Chemischen Forschung, Vol. 42, Springer, Berlin, 95-170. 


\section{Appendix}

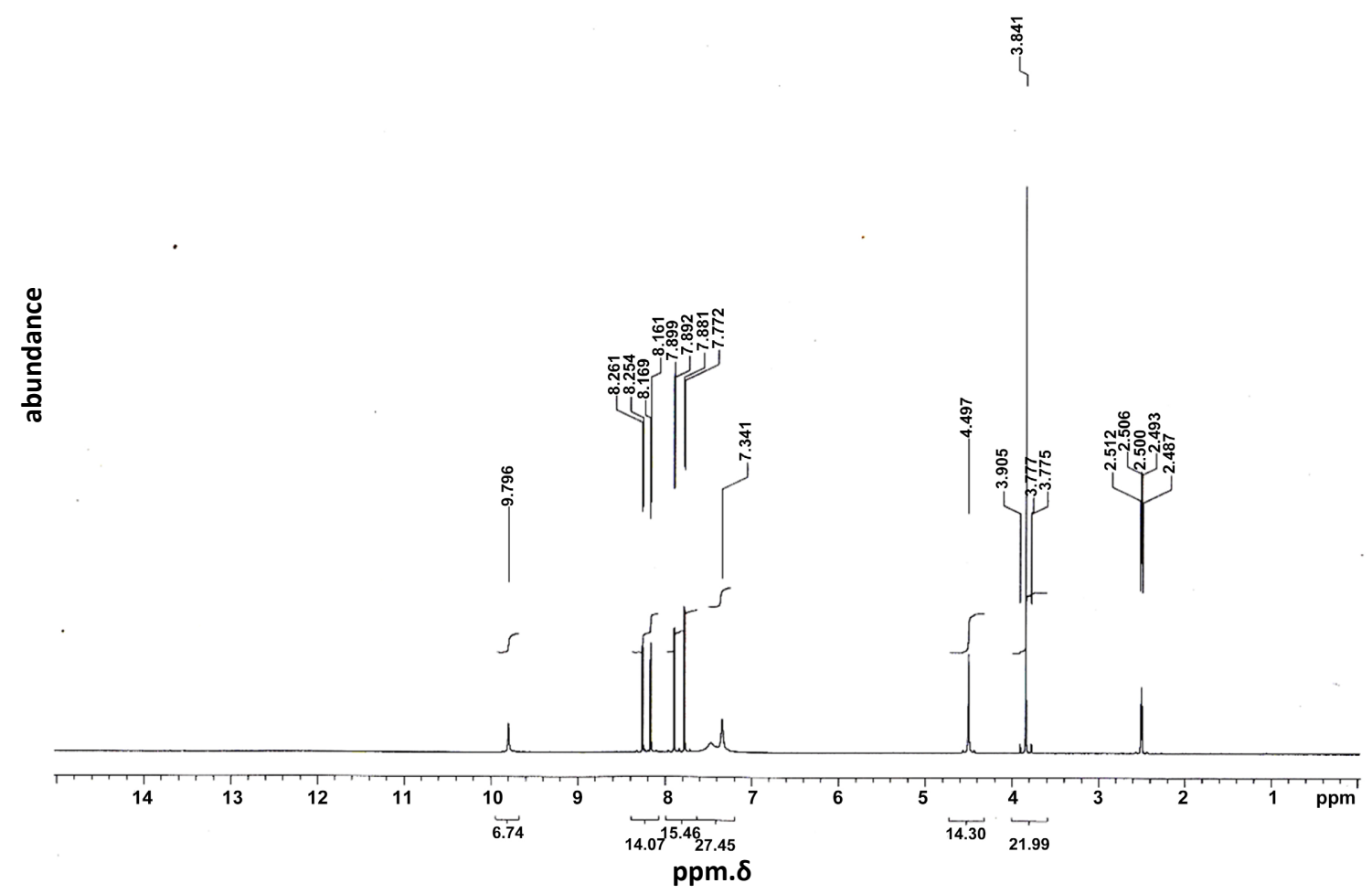

Figure $\mathrm{S} 1 .{ }^{1} \mathrm{H}-\mathrm{NMR}$ spectrum of APA in $\mathrm{d}_{6}$-DMSO.

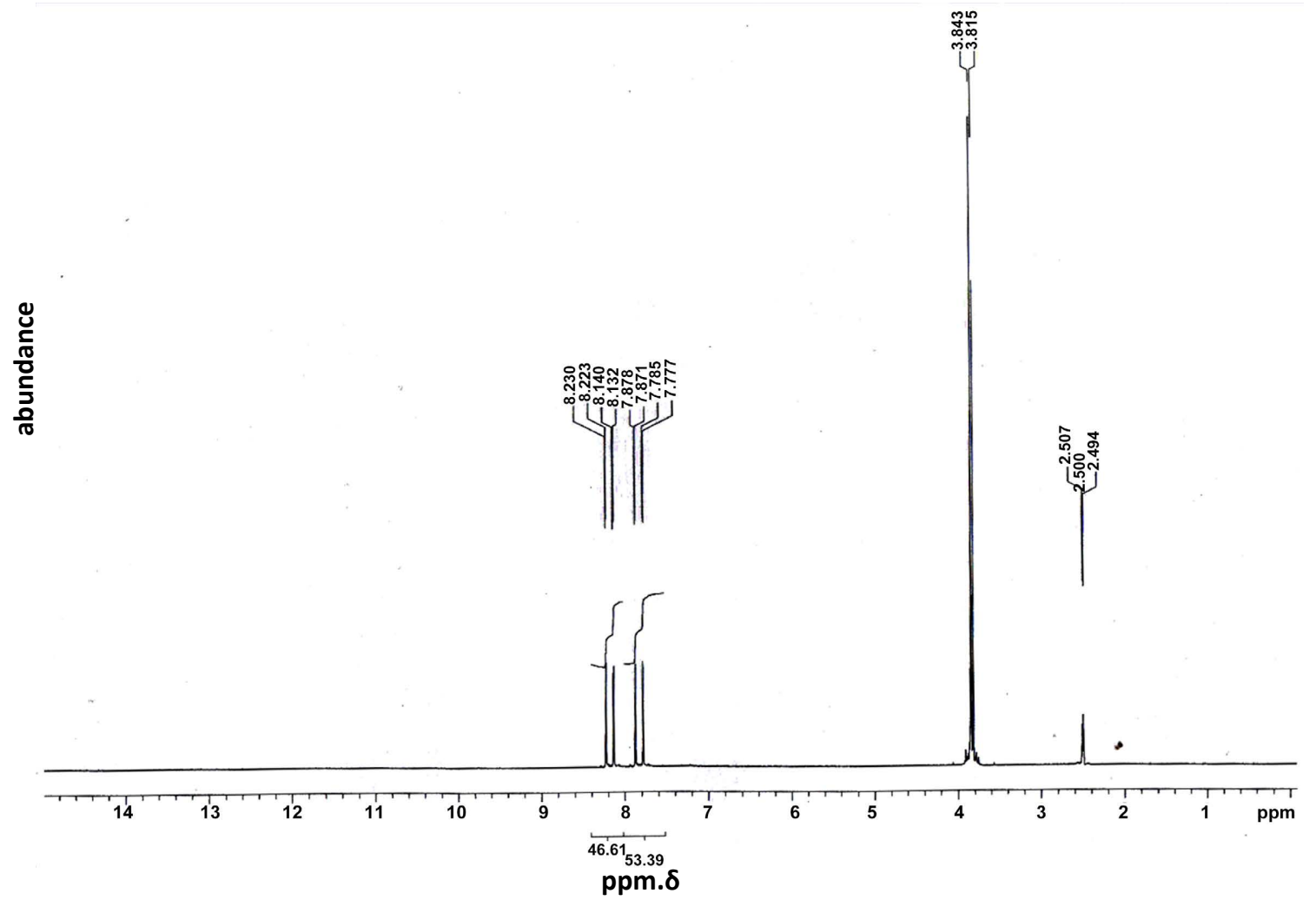

Figure S2. ${ }^{1} \mathrm{H}$-NMR spectrum of APA in $\mathrm{d}_{6}$-DMSO and $\mathrm{D}_{2} \mathrm{O}$. 


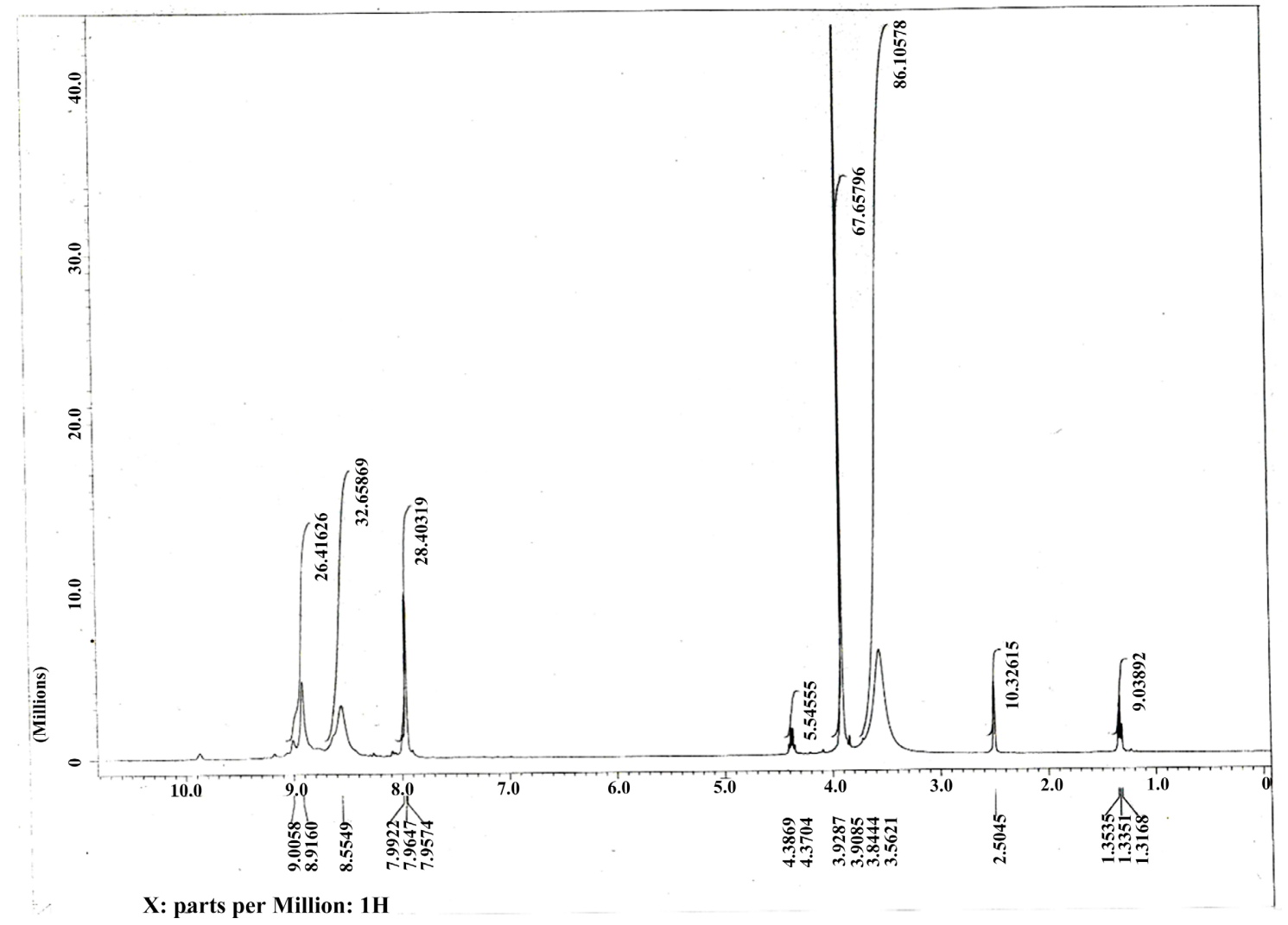

Figure S3. ${ }^{1} \mathrm{H}-\mathrm{NMR}$ spectrum of $\left[\mathrm{Pt}(\mathrm{APA}-\mathrm{H})\left(\mathrm{H}_{2} \mathrm{O}\right) \mathrm{Cl}_{3}\right] \cdot \mathrm{H}_{2} \mathrm{O} \cdot 2 \mathrm{EtOH}$ in $\mathrm{d}_{6}-\mathrm{DMSO}$.

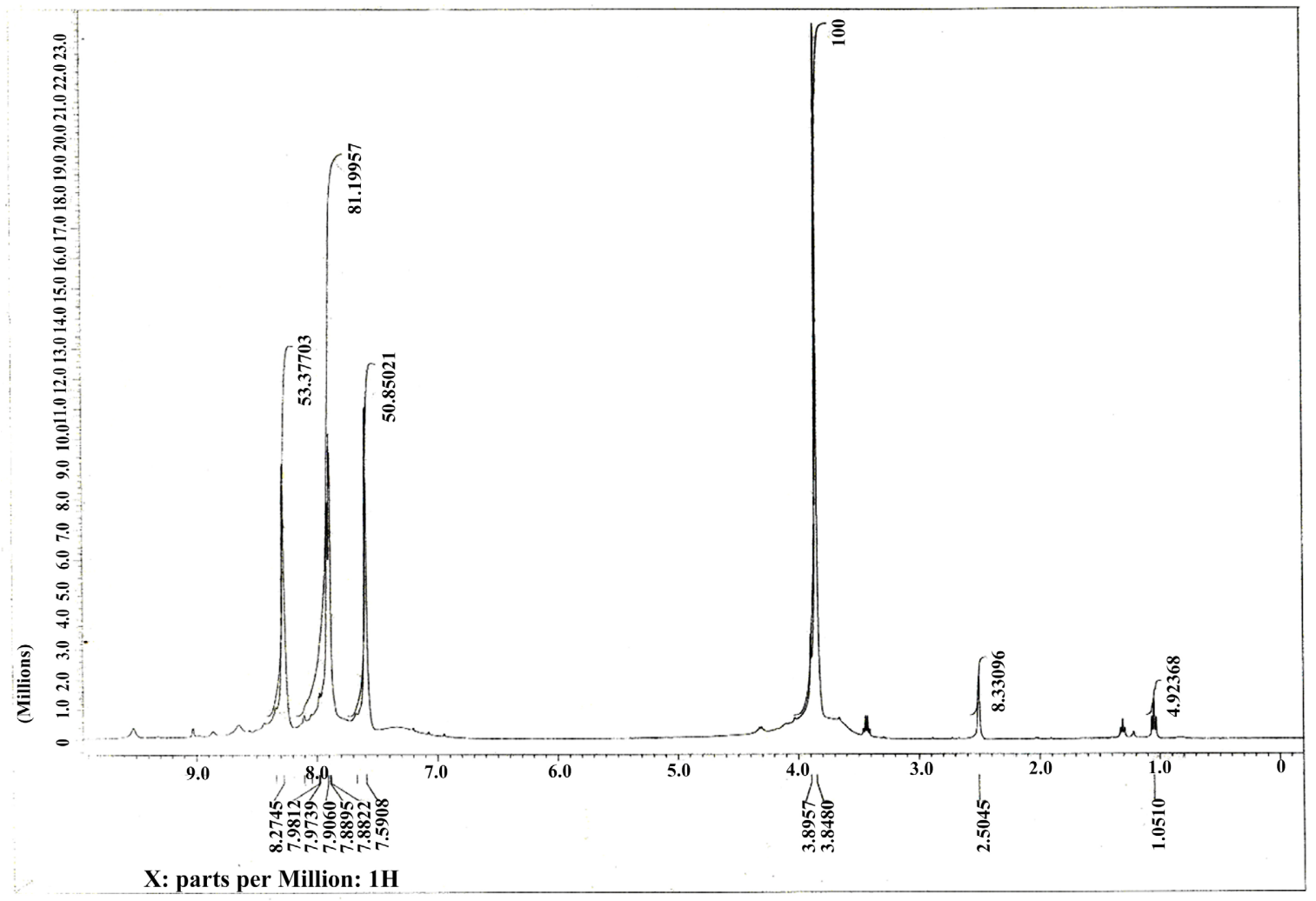

Figure S4. ${ }^{1} \mathrm{H}-\mathrm{NMR}$ spectrum of $\left[\mathrm{Pd}(\mathrm{APA}-\mathrm{H})\left(\mathrm{H}_{2} \mathrm{O}\right) \mathrm{Cl}\right] \cdot 1 / 2 \mathrm{EtOH}$ in $\mathrm{d}_{6} \mathrm{DMSO}$. 


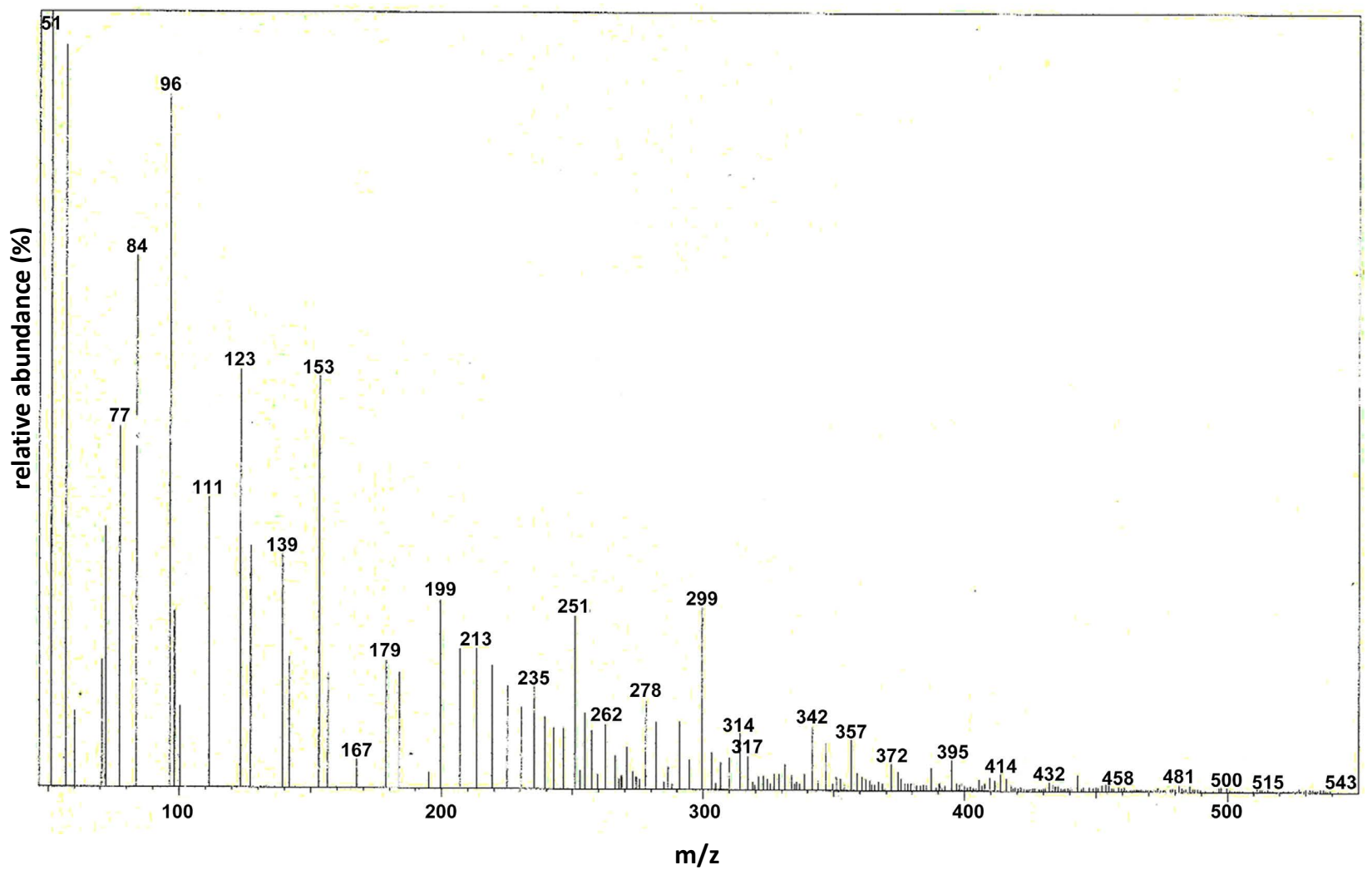

Figure S5. Mass spectrum of $\left[\mathrm{Co}_{2}(\mathrm{APA}-2 \mathrm{H})\left(\mathrm{H}_{2} \mathrm{O}\right)_{2} \mathrm{Cl}_{2}\right] \cdot \mathrm{EtOH}$.

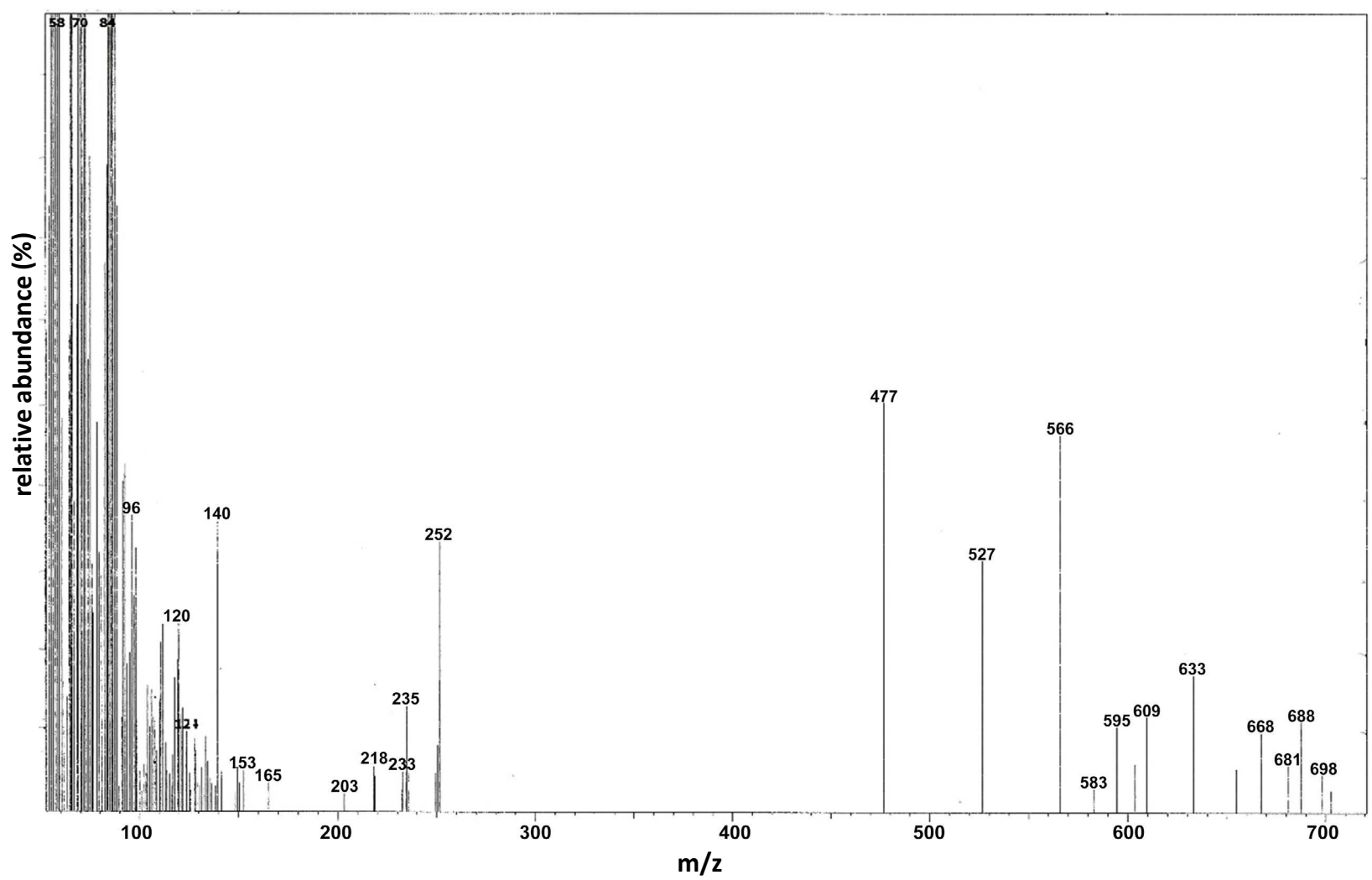

Figure S6. Mass spectrum of $\left[\mathrm{Pt}(\mathrm{APA}-\mathrm{H})\left(\mathrm{H}_{2} \mathrm{O}\right) \mathrm{Cl}_{3}\right] \cdot \mathrm{H}_{2} \mathrm{O} \cdot 2 \mathrm{EtOH}$. 


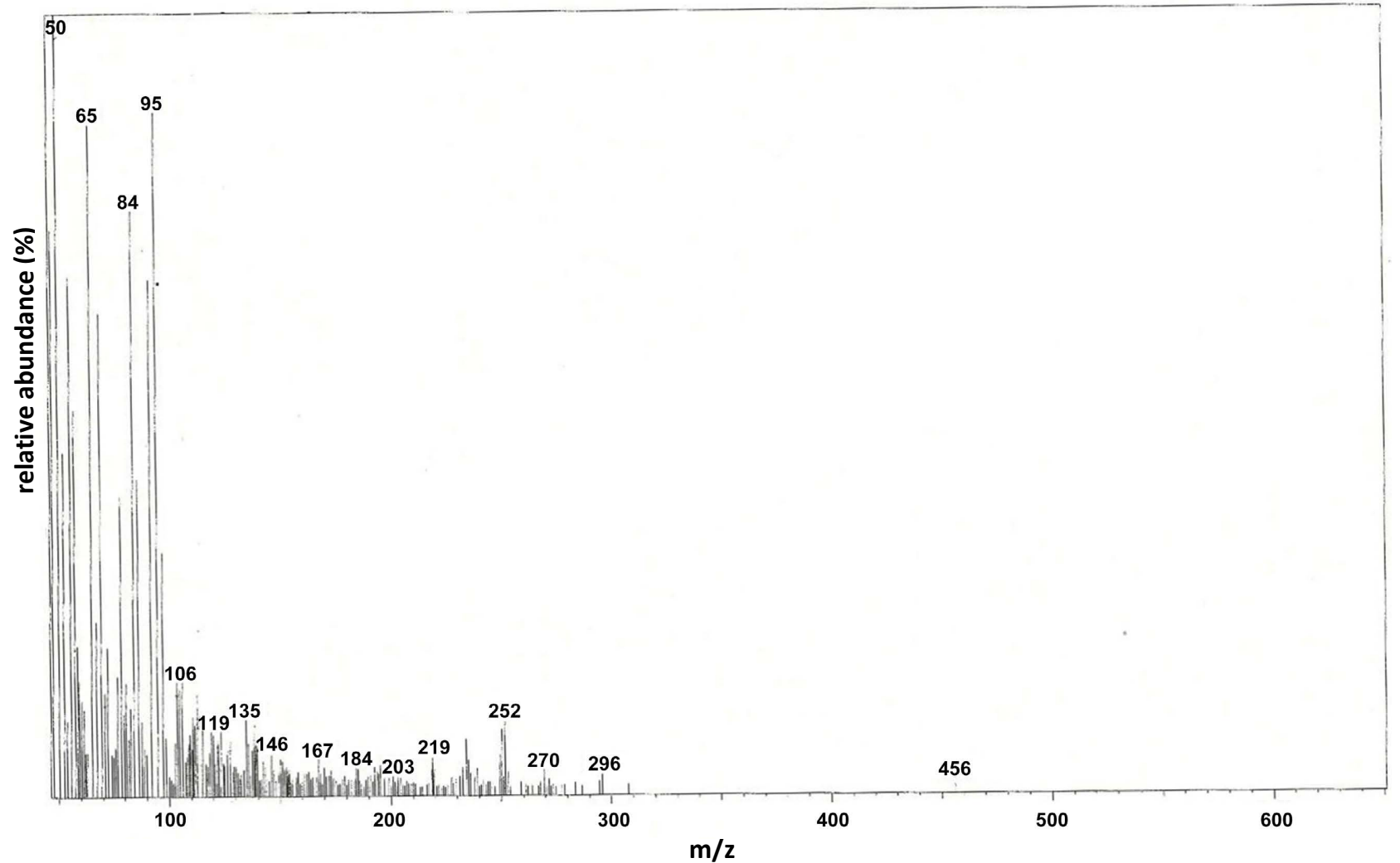

Figure S7. Mass spectrum of $\left[\mathrm{Pd}(\mathrm{APA}-\mathrm{H})\left(\mathrm{H}_{2} \mathrm{O}\right) \mathrm{Cl}\right] \cdot 1 / 2 \mathrm{EtOH}$.

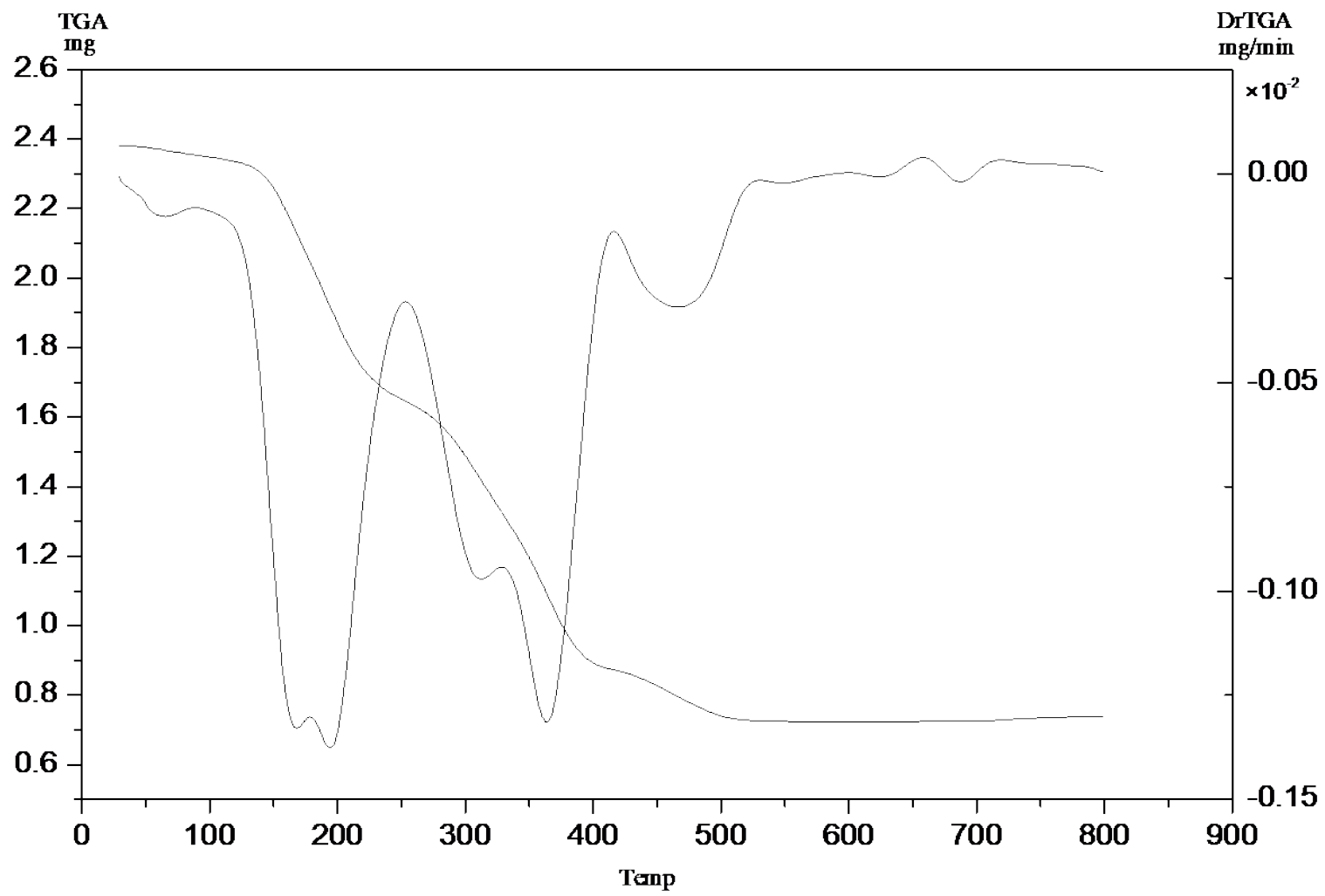

Figure S8. Thermal analysis curves (TGA, DTG) of $\left[\mathrm{Cu}_{2}\left(\right.\right.$ APA-H) $\left.\left(\mathrm{H}_{2} \mathrm{O}\right) \mathrm{Cl}_{3}\right] \cdot \mathrm{H}_{2} \mathrm{O}$. 

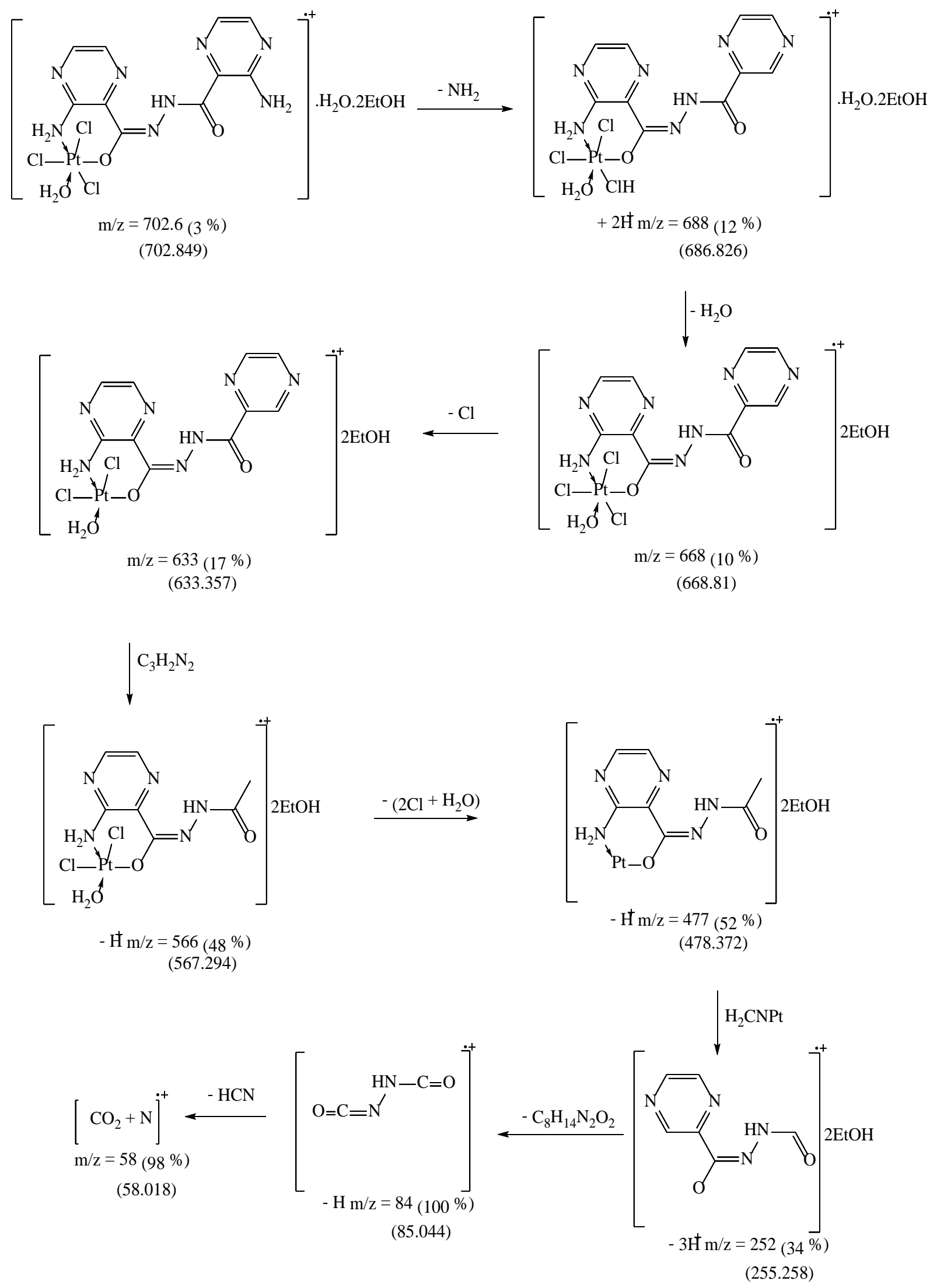

Scheme S1. The main fragments in mass spectrum of $\left[\mathrm{Pt}(\mathrm{APA})-\mathrm{H}\left(\mathrm{H}_{2} \mathrm{O}\right) \mathrm{Cl}_{3}\right] \cdot \mathrm{H}_{2} \mathrm{O} \cdot 2 \mathrm{EtOH}$. 


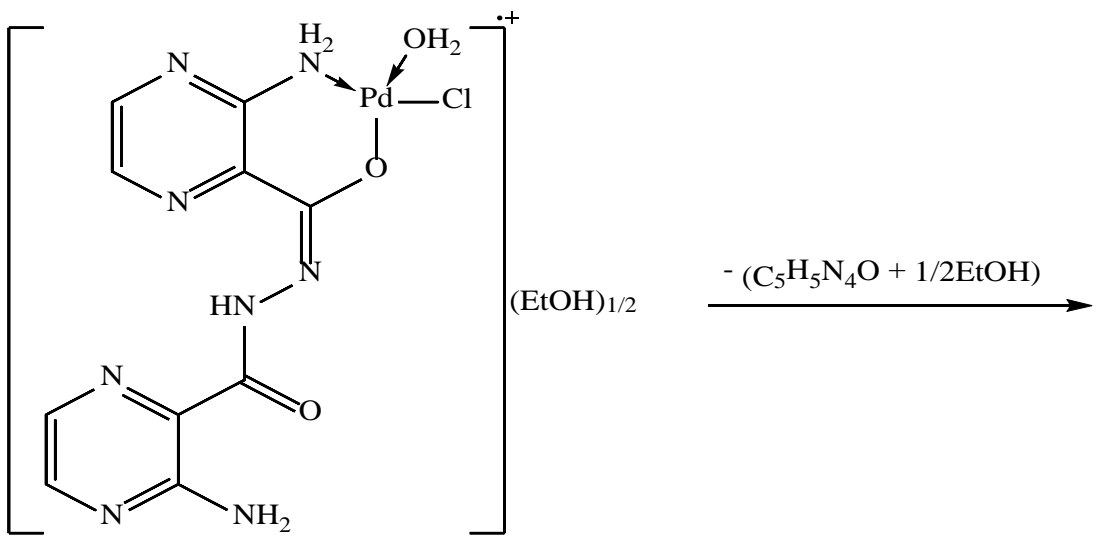

$\mathrm{m} / \mathrm{z}=456$ (2\%)

(456.162)

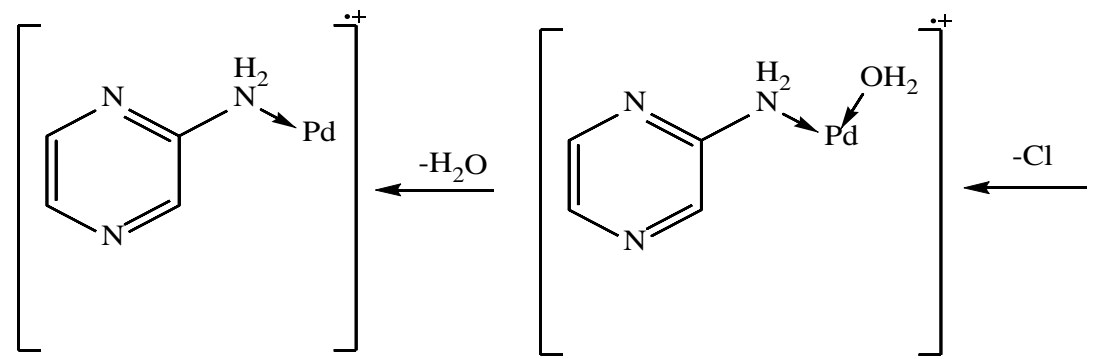

$\mathrm{m} / \mathrm{z}=200(2 \%)$

(200.517)

$\downarrow-\mathrm{Pd}$

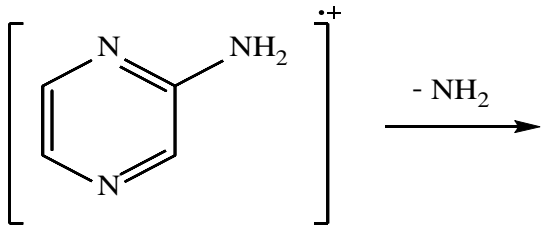

$+\mathrm{H}^{\dagger} \mathrm{m} / \mathrm{z}=95(87 \%)$

(94.097)<smiles>[C+]Cc1ccncn1</smiles>

$\mathrm{m} / \mathrm{z}=78(38 \%)$

(78.074)<smiles>N=C1O[P@@](O)(Cl)Nc2nccnc21</smiles><smiles>[C+]CC</smiles>

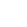

$$
\text { (296.004) }
$$<smiles>[V]OC[Te]</smiles>

$-\mathrm{H}^{+} \mathrm{m} / \mathrm{z}=252$ (9 \%)

(253.986)

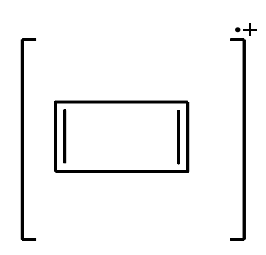

$\mathrm{m} / \mathrm{z}=50(100 \%)$

(50.06)

Scheme S2. The main fragments in mass spectrum of $\left[\mathrm{Pd}(\mathrm{APA}-\mathrm{H})\left(\mathrm{H}_{2} \mathrm{O}\right) \mathrm{Cl}\right] \cdot 1 / 2 \mathrm{EtOH}$. 
Table S1. Bonds lengths ( $)$ of (APA) using DFT-method from DMOL ${ }^{3}$ calculations.

\begin{tabular}{cccccccc}
\hline Bond & Length $(\AA)$ & Bond & Length $(\AA)$ & Bond & Length $(\AA)$ & Bond & Length $(\AA)$ \\
\hline $\mathrm{N}(20)-\mathrm{H}(30)$ & 1.1078 & $\mathrm{C}(15)-\mathrm{N}(20)$ & 1.5109 & $\mathrm{~N}(9)-\mathrm{C}(11)$ & 1.5095 & $\mathrm{C}(4)-\mathrm{C}(5)$ & 1.5426 \\
$\mathrm{~N}(20)-\mathrm{H}(29)$ & 1.1098 & $\mathrm{C}(15)-\mathrm{N}(16)$ & 1.5098 & $\mathrm{~N}(8)-\mathrm{H}(23)$ & 1.1087 & $\mathrm{~N}(3)-\mathrm{C}(4)$ & 1.5095 \\
$\mathrm{~N}(19)-\mathrm{H}(28)$ & 1.1089 & $\mathrm{C}(14)-\mathrm{C}(15)$ & 1.5438 & $\mathrm{~N}(8)-\mathrm{N}(9)$ & 1.479 & $\mathrm{C}(2)-\mathrm{H}(22)$ & 1.1399 \\
$\mathrm{~N}(19)-\mathrm{H}(27)$ & 1.1099 & $\mathrm{C}(18)-\mathrm{N}(13)$ & 1.5095 & $\mathrm{C}(7)-\mathrm{O}(10)$ & 1.5103 & $\mathrm{C}(2)-\mathrm{N}(3)$ & 1.5102 \\
$\mathrm{C}(18)-\mathrm{H}(26)$ & 1.14 & $\mathrm{~N}(13)-\mathrm{C}(14)$ & 1.5098 & $\mathrm{C}(7)-\mathrm{N}(8)$ & 1.5099 & $\mathrm{C}(1)-\mathrm{H}(21)$ & 1.1399 \\
$\mathrm{C}(17)-\mathrm{H}(25)$ & 1.1398 & $\mathrm{O}(12)-\mathrm{H}(24)$ & 1.11 & $\mathrm{C}(5)-\mathrm{N}(19)$ & 1.5107 & $\mathrm{~N}(6)-\mathrm{C}(1)$ & 1.5094 \\
$\mathrm{C}(17)-\mathrm{C}(18)$ & 1.5383 & $\mathrm{C}(14)-\mathrm{C}(11)$ & 1.5419 & $\mathrm{C}(5)-\mathrm{N}(6)$ & 1.5095 & $\mathrm{C}(1)-\mathrm{C}(2)$ & 1.539 \\
$\mathrm{~N}(16)-\mathrm{C}(17)$ & 1.5088 & $\mathrm{C}(11)-\mathrm{O}(12)$ & 1.5079 & $\mathrm{C}(4)-\mathrm{C}(7)$ & 1.542 & & \\
\hline
\end{tabular}

Table S2. Bonds angles $\left(^{\circ}\right)$ of (APA) using DFT-method from DMOL ${ }^{3}$ calculations.

\begin{tabular}{cccccc}
\hline Angle & Degree $\left(^{\circ}\right)$ & Angle & Degree $\left({ }^{\circ}\right)$ & Angle & Degree $\left(^{\circ}\right)$ \\
\hline $\mathrm{H}(30)-\mathrm{N}(20)-\mathrm{H}(29)$ & 119.8083 & $\mathrm{~N}(16)-\mathrm{C}(15)-\mathrm{C}(14)$ & 119.8481 & $\mathrm{~N}(8)-\mathrm{C}(7)-\mathrm{C}(4)$ & 120.0328 \\
$\mathrm{H}(30)-\mathrm{N}(20)-\mathrm{C}(15)$ & 120.4091 & $\mathrm{C}(15)-\mathrm{C}(14)-\mathrm{N}(13)$ & 119.7604 & $\mathrm{C}(5)-\mathrm{N}(6)-\mathrm{C}(1)$ & 120.1135 \\
$\mathrm{H}(29)-\mathrm{N}(20)-\mathrm{C}(15)$ & 119.7821 & $\mathrm{C}(15)-\mathrm{C}(14)-\mathrm{C}(11)$ & 120.849 & $\mathrm{~N}(19)-\mathrm{C}(5)-\mathrm{N}(6)$ & 119.4975 \\
$\mathrm{H}(28)-\mathrm{N}(19)-\mathrm{H}(27)$ & 119.8783 & $\mathrm{~N}(13)-\mathrm{C}(14)-\mathrm{C}(11)$ & 119.3906 & $\mathrm{~N}(19)-\mathrm{C}(5)-\mathrm{C}(4)$ & 120.6217 \\
$\mathrm{H}(28)-\mathrm{N}(19)-\mathrm{C}(5)$ & 120.2226 & $\mathrm{C}(18)-\mathrm{N}(13)-\mathrm{C}(14)$ & 120.2529 & $\mathrm{~N}(6)-\mathrm{C}(5)-\mathrm{C}(4)$ & 119.8576 \\
$\mathrm{H}(27)-\mathrm{N}(19)-\mathrm{C}(5)$ & 119.8853 & $\mathrm{H}(24)-\mathrm{O}(12)-\mathrm{C}(11)$ & 109.5015 & $\mathrm{C}(7)-\mathrm{C}(4)-\mathrm{C}(5)$ & 120.6503 \\
$\mathrm{H}(26)-\mathrm{C}(18)-\mathrm{C}(17)$ & 120.0106 & $\mathrm{C}(14)-\mathrm{C}(11)-\mathrm{O}(12)$ & 120.5572 & $\mathrm{C}(7)-\mathrm{C}(4)-\mathrm{N}(3)$ & 119.6208 \\
$\mathrm{H}(26)-\mathrm{C}(18)-\mathrm{N}(13)$ & 120.0344 & $\mathrm{C}(14)-\mathrm{C}(11)-\mathrm{N}(9)$ & 120.2337 & $\mathrm{C}(5)-\mathrm{C}(4)-\mathrm{N}(3)$ & 119.7171 \\
$\mathrm{C}(17)-\mathrm{C}(18)-\mathrm{N}(13)$ & 119.955 & $\mathrm{O}(12)-\mathrm{C}(11)-\mathrm{N}(9)$ & 119.1791 & $\mathrm{C}(4)-\mathrm{N}(3)-\mathrm{C}(2)$ & 120.108 \\
$\mathrm{H}(25)-\mathrm{C}(17)-\mathrm{C}(18)$ & 120.0382 & $\mathrm{C}(11)-\mathrm{N}(9)-\mathrm{N}(8)$ & 118.9125 & $\mathrm{H}(22)-\mathrm{C}(2)-\mathrm{N}(3)$ & 120.0437 \\
$\mathrm{H}(25)-\mathrm{C}(17)-\mathrm{N}(16)$ & 120.0359 & $\mathrm{H}(23)-\mathrm{N}(8)-\mathrm{N}(9)$ & 119.5355 & $\mathrm{H}(22)-\mathrm{C}(2)-\mathrm{C}(1)$ & 120.0059 \\
$\mathrm{C}(18)-\mathrm{C}(17)-\mathrm{N}(16)$ & 119.9258 & $\mathrm{H}(23)-\mathrm{N}(8)-\mathrm{C}(7)$ & 119.8885 & $\mathrm{~N}(3)-\mathrm{C}(2)-\mathrm{C}(1)$ & 119.9495 \\
$\mathrm{C}(17)-\mathrm{N}(16)-\mathrm{C}(15)$ & 120.2461 & $\mathrm{~N}(9)-\mathrm{N}(8)-\mathrm{C}(7)$ & 120.5228 & $\mathrm{H}(21)-\mathrm{C}(1)-\mathrm{N}(6)$ & 120.041 \\
$\mathrm{~N}(20)-\mathrm{C}(15)-\mathrm{N}(16)$ & 119.2623 & $\mathrm{O}(10)-\mathrm{C}(7)-\mathrm{N}(8)$ & 119.9566 & $\mathrm{H}(21)-\mathrm{C}(1)-\mathrm{C}(2)$ & 120.0285 \\
$\mathrm{~N}(20)-\mathrm{C}(15)-\mathrm{C}(14)$ & 120.8896 & $\mathrm{O}(10)-\mathrm{C}(7)-\mathrm{C}(4)$ & 119.9196 & $\mathrm{~N}(6)-\mathrm{C}(1)-\mathrm{C}(2)$ & 119.9277 \\
\hline
\end{tabular}

Table S3. Bonds lengths $(\AA)$ of $\left[\mathrm{Cu}_{2}(\right.$ APA-H $\left.)\left(\mathrm{H}_{2} \mathrm{O}\right) \mathrm{Cl}_{3}\right] \cdot \mathrm{H}_{2} \mathrm{O}$ using DFT-method from DMOL calculations.

\begin{tabular}{cccccccc}
\hline Bond & Length $(\AA)$ & Bond & Length $(\AA)$ & Bond & Length $(\AA)$ & Bond & Length $(\AA)$ \\
\hline $\mathrm{O}(24)-\mathrm{H}(37)$ & 0.9973 & $\mathrm{~N}(19)-\mathrm{H}(32)$ & 1.0338 & $\mathrm{~N}(13)-\mathrm{C}(14)$ & 1.3817 & $\mathrm{C}(5)-\mathrm{N}(19)$ & 1.4295 \\
$\mathrm{O}(24)-\mathrm{H}(36)$ & 0.9973 & $\mathrm{~N}(19)-\mathrm{Cu}(21)$ & 2.2537 & $\mathrm{O}(12)-\mathrm{Cu}(22)$ & 2.1144 & $\mathrm{C}(5)-\mathrm{N}(6)$ & 1.3596 \\
$\mathrm{O}(24)-\mathrm{Cu}(22)$ & 2.307 & $\mathrm{C}(18)-\mathrm{H}(31)$ & 1.0959 & $\mathrm{C}(14)-\mathrm{C}(11)$ & 1.4721 & $\mathrm{C}(4)-\mathrm{C}(7)$ & 1.4618 \\
$\mathrm{Cl}(23)-\mathrm{Cu}(22)$ & 2.3418 & $\mathrm{C}(17)-\mathrm{H}(30)$ & 1.0955 & $\mathrm{C}(11)-\mathrm{O}(12)$ & 1.3259 & $\mathrm{C}(4)-\mathrm{C}(5)$ & 1.4461 \\
$\mathrm{Cl}(26)-\mathrm{Cu}(21)$ & 2.35 & $\mathrm{C}(17)-\mathrm{C}(18)$ & 1.4239 & $\mathrm{O}(10)-\mathrm{Cu}(21)$ & 2.1479 & $\mathrm{~N}(3)-\mathrm{C}(4)$ & 1.383 \\
$\mathrm{Cl}(25)-\mathrm{Cu}(21)$ & 2.3589 & $\mathrm{~N}(16)-\mathrm{C}(17)$ & 1.3642 & $\mathrm{~N}(9)-\mathrm{C}(11)$ & 1.3743 & $\mathrm{C}(2)-\mathrm{H}(28)$ & 1.097 \\
$\mathrm{~N}(20)-\mathrm{H}(35)$ & 1.0358 & $\mathrm{C}(15)-\mathrm{N}(20)$ & 1.4392 & $\mathrm{~N}(8)-\mathrm{H}(29)$ & 1.0488 & $\mathrm{C}(2)-\mathrm{N}(3)$ & 1.3584 \\
$\mathrm{~N}(20)-\mathrm{H}(34)$ & 1.0389 & $\mathrm{C}(15)-\mathrm{N}(16)$ & 1.3612 & $\mathrm{~N}(8)-\mathrm{N}(9)$ & 1.35 & $\mathrm{C}(1)-\mathrm{H}(27)$ & 1.0968 \\
$\mathrm{~N}(20)-\mathrm{Cu}(22)$ & 2.2372 & $\mathrm{C}(14)-\mathrm{C}(15)$ & 1.4531 & $\mathrm{C}(7)-\mathrm{O}(10)$ & 1.3055 & $\mathrm{~N}(6)-\mathrm{C}(1)$ & 1.3614 \\
$\mathrm{~N}(19)-\mathrm{H}(33)$ & 1.0382 & $\mathrm{C}(18)-\mathrm{N}(13)$ & 1.359 & $\mathrm{C}(7)-\mathrm{N}(8)$ & 1.4 & $\mathrm{C}(1)-\mathrm{C}(2)$ & 1.4276 \\
\hline
\end{tabular}


Table S4. Bonds angles $\left({ }^{\circ}\right)$ of $\left[\mathrm{Cu}_{2}(\right.$ APA-H $\left.)\left(\mathrm{H}_{2} \mathrm{O}\right) \mathrm{Cl}_{3}\right] \cdot \mathrm{H}_{2} \mathrm{O}$ using DFT-method from DMOL ${ }^{3}$ calculations.

\begin{tabular}{|c|c|c|c|c|c|}
\hline Angle & Degree $\left({ }^{\circ}\right)$ & Angle & Degree $\left({ }^{\circ}\right)$ & Angle & Degree $\left({ }^{\circ}\right)$ \\
\hline $\mathrm{H}(37)-\mathrm{O}(24)-\mathrm{H}(36)$ & 104.086 & $\mathrm{H}(33)-\mathrm{N}(19)-\mathrm{C}(5)$ & 113.632 & $\mathrm{C}(11)-\mathrm{N}(9)-\mathrm{N}(8)$ & 119.668 \\
\hline $\mathrm{H}(37)-\mathrm{O}(24)-\mathrm{Cu}(22)$ & 104.421 & $\mathrm{H}(32)-\mathrm{N}(19)-\mathrm{Cu}(21)$ & 111.1704 & $\mathrm{H}(29)-\mathrm{N}(8)-\mathrm{N}(9)$ & 118.3853 \\
\hline $\mathrm{H}(36)-\mathrm{O}(24)-\mathrm{Cu}(22)$ & 109.2731 & $\mathrm{H}(32)-\mathrm{N}(19)-\mathrm{C}(5)$ & 109.4936 & $\mathrm{H}(29)-\mathrm{N}(8)-\mathrm{C}(7)$ & 119.973 \\
\hline $\mathrm{O}(24)-\mathrm{Cu}(22)-\mathrm{Cl}(23)$ & 106.4758 & $\mathrm{Cu}(21)-\mathrm{N}(19)-\mathrm{C}(5)$ & 114.9949 & $\mathrm{~N}(9)-\mathrm{N}(8)-\mathrm{C}(7)$ & 121.6032 \\
\hline $\mathrm{O}(24)-\mathrm{Cu}(22)-\mathrm{N}(20)$ & 105.1124 & $\mathrm{H}(31)-\mathrm{C}(18)-\mathrm{C}(17)$ & 121.7454 & $\mathrm{O}(10)-\mathrm{C}(7)-\mathrm{N}(8)$ & 119.7595 \\
\hline $\mathrm{O}(24)-\mathrm{Cu}(22)-\mathrm{O}(12)$ & 111.9968 & $\mathrm{H}(31)-\mathrm{C}(18)-\mathrm{N}(13)$ & 117.0667 & $\mathrm{O}(10)-\mathrm{C}(7)-\mathrm{C}(4)$ & 125.3761 \\
\hline $\mathrm{Cl}(23)-\mathrm{Cu}(22)-\mathrm{N}(20)$ & 121.7634 & $\mathrm{C}(17)-\mathrm{C}(18)-\mathrm{N}(13)$ & 121.1866 & $\mathrm{~N}(8)-\mathrm{C}(7)-\mathrm{C}(4)$ & 114.8569 \\
\hline $\mathrm{Cl}(23)-\mathrm{Cu}(22)-\mathrm{O}(12)$ & 128.4852 & $\mathrm{H}(30)-\mathrm{C}(17)-\mathrm{C}(18)$ & 122.0378 & $C(5)-N(6)-C(1)$ & 118.0727 \\
\hline $\mathrm{N}(20)-\mathrm{Cu}(22)-\mathrm{O}(12)$ & 79.4743 & $\mathrm{H}(30)-\mathrm{C}(17)-\mathrm{N}(16)$ & 117.5059 & $\mathrm{~N}(19)-\mathrm{C}(5)-\mathrm{N}(6)$ & 116.2464 \\
\hline $\mathrm{Cl}(26)-\mathrm{Cu}(21)-\mathrm{Cl}(25)$ & 121.4286 & $\mathrm{C}(18)-\mathrm{C}(17)-\mathrm{N}(16)$ & 120.4563 & $\mathrm{~N}(19)-\mathrm{C}(5)-\mathrm{C}(4)$ & 121.8344 \\
\hline $\mathrm{Cl}(26)-\mathrm{Cu}(21)-\mathrm{N}(19)$ & 111.214 & $\mathrm{C}(17)-\mathrm{N}(16)-\mathrm{C}(15)$ & 118.5789 & $\mathrm{~N}(6)-\mathrm{C}(5)-\mathrm{C}(4)$ & 121.8834 \\
\hline $\mathrm{Cl}(26)-\mathrm{Cu}(21)-\mathrm{O}(10)$ & 116.756 & $\mathrm{~N}(20)-\mathrm{C}(15)-\mathrm{N}(16)$ & 114.9991 & $C(7)-C(4)-C(5)$ & 123.8421 \\
\hline $\mathrm{Cl}(25)-\mathrm{Cu}(21)-\mathrm{N}(19)$ & 102.41 & $\mathrm{~N}(20)-\mathrm{C}(15)-\mathrm{C}(14)$ & 123.0853 & $\mathrm{C}(7)-\mathrm{C}(4)-\mathrm{N}(3)$ & 117.6196 \\
\hline $\mathrm{Cl}(25)-\mathrm{Cu}(21)-\mathrm{O}(10)$ & 114.7559 & $\mathrm{~N}(16)-\mathrm{C}(15)-\mathrm{C}(14)$ & 121.9146 & $\mathrm{C}(5)-\mathrm{C}(4)-\mathrm{N}(3)$ & 118.5148 \\
\hline $\mathrm{N}(19)-\mathrm{Cu}(21)-\mathrm{O}(10)$ & 81.0071 & $\mathrm{C}(15)-\mathrm{C}(14)-\mathrm{N}(13)$ & 117.6974 & $\mathrm{C}(4)-\mathrm{N}(3)-\mathrm{C}(2)$ & 118.7355 \\
\hline $\mathrm{H}(35)-\mathrm{N}(20)-\mathrm{H}(34)$ & 108.6316 & $C(15)-C(14)-C(11)$ & 124.0972 & $\mathrm{H}(28)-\mathrm{C}(2)-\mathrm{N}(3)$ & 118.012 \\
\hline $\mathrm{H}(35)-\mathrm{N}(20)-\mathrm{Cu}(22)$ & 117.1723 & $\mathrm{~N}(13)-\mathrm{C}(14)-\mathrm{C}(11)$ & 118.1901 & $\mathrm{H}(28)-\mathrm{C}(2)-\mathrm{C}(1)$ & 120.6356 \\
\hline $\mathrm{H}(35)-\mathrm{N}(20)-\mathrm{C}(15)$ & 108.4625 & $\mathrm{C}(18)-\mathrm{N}(13)-\mathrm{C}(14)$ & 119.8418 & $\mathrm{~N}(3)-\mathrm{C}(2)-\mathrm{C}(1)$ & 121.3278 \\
\hline $\mathrm{H}(34)-\mathrm{N}(20)-\mathrm{Cu}(22)$ & 99.8601 & $\mathrm{Cu}(22)-\mathrm{O}(12)-\mathrm{C}(11)$ & 122.14 & $\mathrm{H}(27)-\mathrm{C}(1)-\mathrm{N}(6)$ & 117.6961 \\
\hline $\mathrm{H}(34)-\mathrm{N}(20)-\mathrm{C}(15)$ & 112.5589 & $\mathrm{C}(14)-\mathrm{C}(11)-\mathrm{O}(12)$ & 120.358 & $\mathrm{H}(27)-\mathrm{C}(1)-\mathrm{C}(2)$ & 121.5398 \\
\hline $\mathrm{Cu}(22)-\mathrm{N}(20)-\mathrm{C}(15)$ & 110.0307 & $\mathrm{C}(14)-\mathrm{C}(11)-\mathrm{N}(9)$ & 126.3113 & $\mathrm{~N}(6)-\mathrm{C}(1)-\mathrm{C}(2)$ & 120.7567 \\
\hline $\mathrm{H}(33)-\mathrm{N}(19)-\mathrm{H}(32)$ & 108.7155 & $\mathrm{O}(12)-\mathrm{C}(11)-\mathrm{N}(9)$ & 113.1607 & & \\
\hline $\mathrm{H}(33)-\mathrm{N}(19)-\mathrm{Cu}(21)$ & 98.3312 & $\mathrm{Cu}(21)-\mathrm{O}(10)-\mathrm{C}(7)$ & 125.5608 & & \\
\hline
\end{tabular}

Table S5. Bonds lengths $(\AA)$ of $\left[\mathrm{Co}_{2}(\right.$ APA-2H $\left.)\left(\mathrm{H}_{2} \mathrm{O}\right)_{2} \mathrm{Cl}_{2}\right] \cdot$ EtOH using DFT-method from DMOL ${ }^{3}$ calculations.

\begin{tabular}{cccccccc}
\hline Bond & Length $(\AA)$ & Bond & Length $(\AA)$ & Bond & Length $(\AA)$ & Bond & Length $(\AA)$ \\
\hline $\mathrm{O}(26)-\mathrm{H}(38)$ & 1.1101 & $\mathrm{~N}(19)-\mathrm{H}(32)$ & 1.11 & $\mathrm{~N}(13)-\mathrm{C}(14)$ & 1.5122 & $\mathrm{C}(4)-\mathrm{C}(7)$ & 1.553 \\
$\mathrm{O}(26)-\mathrm{H}(37)$ & 1.11 & $\mathrm{~N}(19)-\mathrm{H}(31)$ & 1.11 & $\mathrm{O}(12)-\mathrm{Co}(22)$ & 1.9364 & $\mathrm{C}(4)-\mathrm{C}(5)$ & 1.5571 \\
$\mathrm{O}(24)-\mathrm{H}(36)$ & 1.11 & $\mathrm{~N}(19)-\mathrm{Co}(21)$ & 1.9399 & $\mathrm{C}(14)-\mathrm{C}(11)$ & 1.5538 & $\mathrm{~N}(3)-\mathrm{C}(4)$ & 1.5121 \\
$\mathrm{O}(24)-\mathrm{H}(35)$ & 1.11 & $\mathrm{C}(18)-\mathrm{H}(30)$ & 1.1399 & $\mathrm{C}(11)-\mathrm{O}(12)$ & 1.5096 & $\mathrm{C}(2)-\mathrm{H}(28)$ & 1.1401 \\
$\mathrm{O}(24)-\mathrm{Co}(22)$ & 1.9502 & $\mathrm{C}(17)-\mathrm{H}(29)$ & 1.14 & $\mathrm{O}(10)-\mathrm{Co}(21)$ & 1.9361 & $\mathrm{C}(2)-\mathrm{N}(3)$ & 1.5089 \\
$\mathrm{Cl}(23)-\mathrm{Co}(22)$ & 2.2011 & $\mathrm{C}(17)-\mathrm{C}(18)$ & 1.536 & $\mathrm{~N}(9)-\mathrm{C}(11)$ & 1.5101 & $\mathrm{C}(1)-\mathrm{H}(27)$ & 1.14 \\
$\mathrm{O}(26)-\mathrm{Co}(21)$ & 1.9497 & $\mathrm{~N}(16)-\mathrm{C}(17)$ & 1.5075 & $\mathrm{~N}(8)-\mathrm{N}(9)$ & 1.4791 & $\mathrm{~N}(6)-\mathrm{C}(1)$ & 1.5077 \\
$\mathrm{Cl}(25)-\mathrm{Co}(21)$ & 2.2004 & $\mathrm{C}(15)-\mathrm{N}(20)$ & 1.5119 & $\mathrm{C}(7)-\mathrm{O}(10)$ & 1.5099 & $\mathrm{C}(1)-\mathrm{C}(2)$ & 1.5364 \\
$\mathrm{~N}(20)-\mathrm{H}(34)$ & 1.1101 & $\mathrm{C}(15)-\mathrm{N}(16)$ & 1.5114 & $\mathrm{C}(7)-\mathrm{N}(8)$ & 1.5086 & & \\
$\mathrm{~N}(20)-\mathrm{H}(33)$ & 1.1099 & $\mathrm{C}(14)-\mathrm{C}(15)$ & 1.557 & $\mathrm{C}(5)-\mathrm{N}(19)$ & 1.5121 & & \\
$\mathrm{~N}(20)-\mathrm{Co}(22)$ & 1.9391 & $\mathrm{C}(18)-\mathrm{N}(13)$ & 1.5087 & $\mathrm{C}(5)-\mathrm{N}(6)$ & 1.5113 & & \\
\hline
\end{tabular}


Table S6. Bonds angles $\left({ }^{\circ}\right)$ of $\left[\mathrm{Co}_{2}\left(\right.\right.$ APA-2H) $\left.\left(\mathrm{H}_{2} \mathrm{O}\right)_{2} \mathrm{Cl}_{2}\right] \cdot$ EtOH using DFT-method from DMOL ${ }^{3}$ calculations.

\begin{tabular}{|c|c|c|c|c|c|}
\hline Angle & Degree $\left({ }^{\circ}\right)$ & Angle & Degree $\left({ }^{\circ}\right)$ & Angle & Degree $\left({ }^{\circ}\right)$ \\
\hline $\mathrm{H}(38)-\mathrm{O}(26)-\mathrm{H}(37)$ & 109.4302 & $\mathrm{Co}(22)-\mathrm{N}(20)-\mathrm{C}(15)$ & 109.6599 & $\mathrm{C}(14)-\mathrm{C}(11)-\mathrm{N}(9)$ & 119.5847 \\
\hline $\mathrm{H}(38)-\mathrm{O}(26)-\mathrm{Co}(21)$ & 109.2133 & $\mathrm{H}(32)-\mathrm{N}(19)-\mathrm{H}(31)$ & 109.4227 & $\mathrm{O}(12)-\mathrm{C}(11)-\mathrm{N}(9)$ & 117.9303 \\
\hline $\mathrm{H}(37)-\mathrm{O}(26)-\mathrm{Co}(21)$ & 109.4171 & $\mathrm{H}(32)-\mathrm{N}(19)-\mathrm{Co}(21)$ & 109.3682 & $\mathrm{Co}(21)-\mathrm{O}(10)-\mathrm{C}(7)$ & 107.6198 \\
\hline $\mathrm{H}(36)-\mathrm{O}(24)-\mathrm{H}(35)$ & 109.4408 & $\mathrm{H}(32)-\mathrm{N}(19)-\mathrm{C}(5)$ & 108.9992 & $\mathrm{C}(11)-\mathrm{N}(9)-\mathrm{N}(8)$ & 121.5672 \\
\hline $\mathrm{H}(36)-\mathrm{O}(24)-\mathrm{Co}(22)$ & 109.4173 & $\mathrm{H}(31)-\mathrm{N}(19)-\mathrm{Co}(21)$ & 109.802 & $\mathrm{~N}(9)-\mathrm{N}(8)-\mathrm{C}(7)$ & 118.5908 \\
\hline $\mathrm{H}(35)-\mathrm{O}(24)-\mathrm{Co}(22)$ & 109.4902 & $\mathrm{H}(31)-\mathrm{N}(19)-\mathrm{C}(5)$ & 109.8154 & $\mathrm{O}(10)-\mathrm{C}(7)-\mathrm{N}(8)$ & 118.0668 \\
\hline $\mathrm{O}(24)-\mathrm{Co}(22)-\mathrm{Cl}(23)$ & 111.0168 & $\mathrm{Co}(21)-\mathrm{N}(19)-\mathrm{C}(5)$ & 109.4161 & $\mathrm{O}(10)-\mathrm{C}(7)-\mathrm{C}(4)$ & 122.6228 \\
\hline $\mathrm{O}(24)-\mathrm{Co}(22)-\mathrm{N}(20)$ & 111.9964 & $\mathrm{H}(30)-\mathrm{C}(18)-\mathrm{C}(17)$ & 120.029 & $\mathrm{~N}(8)-\mathrm{C}(7)-\mathrm{C}(4)$ & 119.2666 \\
\hline $\mathrm{O}(24)-\mathrm{Co}(22)-\mathrm{O}(12)$ & 112.0431 & $\mathrm{H}(30)-\mathrm{C}(18)-\mathrm{N}(13)$ & 120.0525 & $\mathrm{C}(5)-\mathrm{N}(6)-\mathrm{C}(1)$ & 120.6745 \\
\hline $\mathrm{Cl}(23)-\mathrm{Co}(22)-\mathrm{N}(20)$ & 111.4271 & $\mathrm{C}(17)-\mathrm{C}(18)-\mathrm{N}(13)$ & 119.9185 & $\mathrm{~N}(19)-\mathrm{C}(5)-\mathrm{N}(6)$ & 117.9891 \\
\hline $\mathrm{Cl}(23)-\mathrm{Co}(22)-\mathrm{O}(12)$ & 110.4816 & $\mathrm{H}(29)-\mathrm{C}(17)-\mathrm{C}(18)$ & 120.0868 & $\mathrm{~N}(19)-\mathrm{C}(5)-\mathrm{C}(4)$ & 122.2724 \\
\hline $\mathrm{N}(20)-\mathrm{Co}(22)-\mathrm{O}(12)$ & 99.3834 & $\mathrm{H}(29)-\mathrm{C}(17)-\mathrm{N}(16)$ & 120.1165 & $\mathrm{~N}(6)-\mathrm{C}(5)-\mathrm{C}(4)$ & 119.6257 \\
\hline $\mathrm{O}(26)-\mathrm{Co}(21)-\mathrm{Cl}(25)$ & 111.2416 & $\mathrm{C}(18)-\mathrm{C}(17)-\mathrm{N}(16)$ & 119.7966 & $C(7)-C(4)-C(5)$ & 123.4378 \\
\hline $\mathrm{O}(26)-\mathrm{Co}(21)-\mathrm{N}(19)$ & 111.6896 & $\mathrm{C}(17)-\mathrm{N}(16)-\mathrm{C}(15)$ & 120.7084 & $\mathrm{C}(7)-\mathrm{C}(4)-\mathrm{N}(3)$ & 117.4794 \\
\hline $\mathrm{O}(26)-\mathrm{Co}(21)-\mathrm{O}(10)$ & 110.682 & $\mathrm{~N}(20)-\mathrm{C}(15)-\mathrm{N}(16)$ & 117.9179 & $\mathrm{C}(5)-\mathrm{C}(4)-\mathrm{N}(3)$ & 119.0759 \\
\hline $\mathrm{Cl}(25)-\mathrm{Co}(21)-\mathrm{N}(19)$ & 111.7693 & $\mathrm{~N}(20)-\mathrm{C}(15)-\mathrm{C}(14)$ & 122.3096 & $\mathrm{C}(4)-\mathrm{N}(3)-\mathrm{C}(2)$ & 120.8485 \\
\hline $\mathrm{Cl}(25)-\mathrm{Co}(21)-\mathrm{O}(10)$ & 111.351 & $\mathrm{~N}(16)-\mathrm{C}(15)-\mathrm{C}(14)$ & 119.6592 & $\mathrm{H}(28)-\mathrm{C}(2)-\mathrm{N}(3)$ & 120.0426 \\
\hline $\mathrm{N}(19)-\mathrm{Co}(21)-\mathrm{O}(10)$ & 99.6008 & $\mathrm{C}(15)-\mathrm{C}(14)-\mathrm{N}(13)$ & 118.9783 & $\mathrm{H}(28)-\mathrm{C}(2)-\mathrm{C}(1)$ & 120.035 \\
\hline $\mathrm{H}(34)-\mathrm{N}(20)-\mathrm{H}(33)$ & 109.4637 & $C(15)-C(14)-C(11)$ & 123.3267 & $\mathrm{~N}(3)-\mathrm{C}(2)-\mathrm{C}(1)$ & 119.9222 \\
\hline $\mathrm{H}(34)-\mathrm{N}(20)-\mathrm{Co}(22)$ & 109.562 & $\mathrm{~N}(13)-\mathrm{C}(14)-\mathrm{C}(11)$ & 117.6894 & $\mathrm{H}(27)-\mathrm{C}(1)-\mathrm{N}(6)$ & 120.0678 \\
\hline $\mathrm{H}(34)-\mathrm{N}(20)-\mathrm{C}(15)$ & 109.9549 & $\mathrm{C}(18)-\mathrm{N}(13)-\mathrm{C}(14)$ & 120.9323 & $\mathrm{H}(27)-\mathrm{C}(1)-\mathrm{C}(2)$ & 120.0938 \\
\hline $\mathrm{H}(33)-\mathrm{N}(20)-\mathrm{Co}(22)$ & 109.2137 & $\mathrm{Co}(22)-\mathrm{O}(12)-\mathrm{C}(11)$ & 107.1183 & $\mathrm{~N}(6)-\mathrm{C}(1)-\mathrm{C}(2)$ & 119.8385 \\
\hline $\mathrm{H}(33)-\mathrm{N}(20)-\mathrm{C}(15)$ & 108.9691 & $\mathrm{C}(14)-\mathrm{C}(11)-\mathrm{O}(12)$ & 122.4387 & & \\
\hline
\end{tabular}

Table S7. Bonds lengths $(\AA)$ of $\left[\mathrm{Pt}(\right.$ APA-H $\left.)\left(\mathrm{H}_{2} \mathrm{O}\right) \mathrm{Cl}_{3}\right] \cdot \mathrm{H}_{2} \mathrm{O} \cdot 2 \mathrm{EtOH}$ using DFT-method from $\mathrm{DMOL}^{3}$ calculations.

\begin{tabular}{cccccccc}
\hline Bond & Length $(\AA)$ & Bond & Length $(\AA)$ & Bond & Length $(\AA)$ & Bond & Length $(\AA)$ \\
\hline $\mathrm{O}(23)-\mathrm{H}(36)$ & 1.11 & $\mathrm{~N}(19)-\mathrm{H}(31)$ & 1.1101 & $\mathrm{O}(12)-\mathrm{Pt}(21)$ & 2.0993 & $\mathrm{C}(4)-\mathrm{C}(7)$ & 1.5419 \\
$\mathrm{O}(23)-\mathrm{H}(35)$ & 1.11 & $\mathrm{C}(18)-\mathrm{H}(30)$ & 1.1401 & $\mathrm{C}(14)-\mathrm{C}(11)$ & 1.5548 & $\mathrm{C}(4)-\mathrm{C}(5)$ & 1.5449 \\
$\mathrm{Cl}(25)-\mathrm{Pt}(21)$ & 2.3556 & $\mathrm{C}(17)-\mathrm{H}(29)$ & 1.1399 & $\mathrm{C}(11)-\mathrm{O}(12)$ & 1.5088 & $\mathrm{~N}(3)-\mathrm{C}(4)$ & 1.5104 \\
$\mathrm{Cl}(24)-\mathrm{Pt}(21)$ & 2.3582 & $\mathrm{C}(17)-\mathrm{C}(18)$ & 1.5356 & $\mathrm{~N}(9)-\mathrm{C}(11)$ & 1.5147 & $\mathrm{C}(2)-\mathrm{H}(27)$ & 1.14 \\
$\mathrm{O}(23)-\mathrm{Pt}(21)$ & 2.109 & $\mathrm{~N}(16)-\mathrm{C}(17)$ & 1.5073 & $\mathrm{~N}(8)-\mathrm{H}(28)$ & 1.1071 & $\mathrm{C}(2)-\mathrm{N}(3)$ & 1.5094 \\
$\mathrm{Cl}(22)-\mathrm{Pt}(21)$ & 2.3583 & $\mathrm{C}(15)-\mathrm{N}(20)$ & 1.5138 & $\mathrm{~N}(8)-\mathrm{N}(9)$ & 1.4809 & $\mathrm{C}(1)-\mathrm{H}(26)$ & 1.14 \\
$\mathrm{~N}(20)-\mathrm{H}(34)$ & 1.1102 & $\mathrm{C}(15)-\mathrm{N}(16)$ & 1.512 & $\mathrm{C}(7)-\mathrm{O}(10)$ & 1.5089 & $\mathrm{~N}(6)-\mathrm{C}(1)$ & 1.5094 \\
$\mathrm{~N}(20)-\mathrm{H}(33)$ & 1.1102 & $\mathrm{C}(14)-\mathrm{C}(15)$ & 1.5575 & $\mathrm{C}(7)-\mathrm{N}(8)$ & 1.5096 & $\mathrm{C}(1)-\mathrm{C}(2)$ & 1.539 \\
$\mathrm{~N}(20)-\mathrm{Pt}(21)$ & 2.1059 & $\mathrm{C}(18)-\mathrm{N}(13)$ & 1.508 & $\mathrm{C}(5)-\mathrm{N}(19)$ & 1.511 & & \\
$\mathrm{~N}(19)-\mathrm{H}(32)$ & 1.1079 & $\mathrm{~N}(13)-\mathrm{C}(14)$ & 1.5112 & $\mathrm{C}(5)-\mathrm{N}(6)$ & 1.5111 & &
\end{tabular}


Table S8. Bond angles $\left({ }^{\circ}\right)$ of $\left[\mathrm{Pt}(\right.$ APA-H $\left.)\left(\mathrm{H}_{2} \mathrm{O}\right) \mathrm{Cl}_{3}\right] \cdot \mathrm{H}_{2} \mathrm{O} \cdot 2 \mathrm{EtOH}$ using DFT-method from DMOL ${ }^{3}$ calculations.

\begin{tabular}{|c|c|c|c|c|c|}
\hline Angle & Degree $\left({ }^{\circ}\right)$ & Angle & Degree $\left({ }^{\circ}\right)$ & Angle & Degree $\left(^{\circ}\right)$ \\
\hline $\mathrm{H}(36)-\mathrm{O}(23)-\mathrm{H}(35)$ & 109.5042 & $\mathrm{H}(33)-\mathrm{N}(20)-\mathrm{C}(15)$ & 108.6103 & $\mathrm{O}(12)-\mathrm{C}(11)-\mathrm{N}(9)$ & 117.6962 \\
\hline $\mathrm{H}(36)-\mathrm{O}(23)-\mathrm{Pt}(21)$ & 109.4916 & $\operatorname{Pt}(21)-\mathrm{N}(20)-\mathrm{C}(15)$ & 113.8931 & $\mathrm{C}(11)-\mathrm{N}(9)-\mathrm{N}(8)$ & 122.2549 \\
\hline $\mathrm{H}(35)-\mathrm{O}(23)-\mathrm{Pt}(21)$ & 109.4627 & $\mathrm{H}(32)-\mathrm{N}(19)-\mathrm{H}(31)$ & 119.8452 & $\mathrm{H}(28)-\mathrm{N}(8)-\mathrm{N}(9)$ & 120.5454 \\
\hline $\mathrm{Cl}(25)-\mathrm{Pt}(21)-\mathrm{Cl}(24)$ & 89.944 & $\mathrm{H}(32)-\mathrm{N}(19)-\mathrm{C}(5)$ & 120.3349 & $\mathrm{H}(28)-\mathrm{N}(8)-\mathrm{C}(7)$ & 119.7174 \\
\hline $\mathrm{Cl}(25)-\mathrm{Pt}(21)-\mathrm{O}(23)$ & 89.9361 & $\mathrm{H}(31)-\mathrm{N}(19)-\mathrm{C}(5)$ & 119.8198 & $\mathrm{~N}(9)-\mathrm{N}(8)-\mathrm{C}(7)$ & 119.7369 \\
\hline $\mathrm{Cl}(25)-\mathrm{Pt}(21)-\mathrm{Cl}(22)$ & 89.5533 & $\mathrm{H}(30)-\mathrm{C}(18)-\mathrm{C}(17)$ & 120.0703 & $\mathrm{O}(10)-\mathrm{C}(7)-\mathrm{N}(8)$ & 119.6681 \\
\hline $\mathrm{Cl}(25)-\mathrm{Pt}(21)-\mathrm{N}(20)$ & 179.3994 & $\mathrm{H}(30)-\mathrm{C}(18)-\mathrm{N}(13)$ & 120.0682 & $\mathrm{O}(10)-\mathrm{C}(7)-\mathrm{C}(4)$ & 120.7759 \\
\hline $\mathrm{Cl}(25)-\mathrm{Pt}(21)-\mathrm{O}(12)$ & 90.3169 & $\mathrm{C}(17)-\mathrm{C}(18)-\mathrm{N}(13)$ & 119.8615 & $\mathrm{~N}(8)-\mathrm{C}(7)-\mathrm{C}(4)$ & 119.556 \\
\hline $\mathrm{Cl}(24)-\mathrm{Pt}(21)-\mathrm{O}(23)$ & 89.7542 & $\mathrm{H}(29)-\mathrm{C}(17)-\mathrm{C}(18)$ & 120.1036 & $C(5)-N(6)-C(1)$ & 120.2071 \\
\hline $\mathrm{Cl}(24)-\mathrm{Pt}(21)-\mathrm{Cl}(22)$ & 179.2842 & $\mathrm{H}(29)-\mathrm{C}(17)-\mathrm{N}(16)$ & 120.1069 & $\mathrm{~N}(19)-\mathrm{C}(5)-\mathrm{N}(6)$ & 119.3033 \\
\hline $\mathrm{Cl}(24)-\mathrm{Pt}(21)-\mathrm{N}(20)$ & 90.2003 & $\mathrm{C}(18)-\mathrm{C}(17)-\mathrm{N}(16)$ & 119.7893 & $\mathrm{~N}(19)-\mathrm{C}(5)-\mathrm{C}(4)$ & 120.859 \\
\hline $\mathrm{Cl}(24)-\mathrm{Pt}(21)-\mathrm{O}(12)$ & 90.071 & $\mathrm{C}(17)-\mathrm{N}(16)-\mathrm{C}(15)$ & 120.7419 & $\mathrm{~N}(6)-\mathrm{C}(5)-\mathrm{C}(4)$ & 119.8377 \\
\hline $\mathrm{O}(23)-\mathrm{Pt}(21)-\mathrm{Cl}(22)$ & 89.7357 & $\mathrm{~N}(20)-\mathrm{C}(15)-\mathrm{N}(16)$ & 117.5192 & $C(7)-C(4)-C(5)$ & 121.072 \\
\hline $\mathrm{O}(23)-\mathrm{Pt}(21)-\mathrm{N}(20)$ & 90.6476 & $\mathrm{~N}(20)-\mathrm{C}(15)-\mathrm{C}(14)$ & 122.7561 & $\mathrm{C}(7)-\mathrm{C}(4)-\mathrm{N}(3)$ & 119.1444 \\
\hline $\mathrm{O}(23)-\mathrm{Pt}(21)-\mathrm{O}(12)$ & 179.6923 & $\mathrm{~N}(16)-\mathrm{C}(15)-\mathrm{C}(14)$ & 119.6207 & $\mathrm{C}(5)-\mathrm{C}(4)-\mathrm{N}(3)$ & 119.7832 \\
\hline $\mathrm{Cl}(22)-\mathrm{Pt}(21)-\mathrm{N}(20)$ & 90.3076 & $\mathrm{C}(15)-\mathrm{C}(14)-\mathrm{N}(13)$ & 118.9046 & $\mathrm{C}(4)-\mathrm{N}(3)-\mathrm{C}(2)$ & 120.233 \\
\hline $\mathrm{Cl}(22)-\mathrm{Pt}(21)-\mathrm{O}(12)$ & 90.4413 & $\mathrm{C}(15)-\mathrm{C}(14)-\mathrm{C}(11)$ & 122.9298 & $\mathrm{H}(27)-\mathrm{C}(2)-\mathrm{N}(3)$ & 120.005 \\
\hline $\mathrm{N}(20)-\mathrm{Pt}(21)-\mathrm{O}(12)$ & 89.0999 & $\mathrm{~N}(13)-\mathrm{C}(14)-\mathrm{C}(11)$ & 118.1577 & $\mathrm{H}(27)-\mathrm{C}(2)-\mathrm{C}(1)$ & 120.0077 \\
\hline $\mathrm{H}(34)-\mathrm{N}(20)-\mathrm{H}(33)$ & 108.6236 & $\mathrm{C}(18)-\mathrm{N}(13)-\mathrm{C}(14)$ & 121.0771 & $\mathrm{~N}(3)-\mathrm{C}(2)-\mathrm{C}(1)$ & 119.9873 \\
\hline $\mathrm{H}(34)-\mathrm{N}(20)-\mathrm{Pt}(21)$ & 108.5445 & $\mathrm{Pt}(21)-\mathrm{O}(12)-\mathrm{C}(11)$ & 109.3031 & $\mathrm{H}(26)-\mathrm{C}(1)-\mathrm{N}(6)$ & 120.0192 \\
\hline $\mathrm{H}(34)-\mathrm{N}(20)-\mathrm{C}(15)$ & 108.4817 & $\mathrm{C}(14)-\mathrm{C}(11)-\mathrm{O}(12)$ & 121.8095 & $\mathrm{H}(26)-\mathrm{C}(1)-\mathrm{C}(2)$ & 120.0312 \\
\hline $\mathrm{H}(33)-\mathrm{N}(20)-\mathrm{Pt}(21)$ & 108.5761 & $\mathrm{C}(14)-\mathrm{C}(11)-\mathrm{N}(9)$ & 120.4931 & $N(6)-C(1)-C(2)$ & 119.9495 \\
\hline
\end{tabular}

Table S9. Bond lengths $(\AA)$ of $\left[\mathrm{Pd}(\mathrm{APA}-\mathrm{H})\left(\mathrm{H}_{2} \mathrm{O}\right) \mathrm{Cl}\right] \cdot(\mathrm{EtOH})_{1 / 2}$ using DFT-method from $\mathrm{DMOL}^{3}$ calculations.

\begin{tabular}{cccccccc}
\hline Bond & Length $(\AA)$ & Bond & Length $(\AA)$ & Bond & Length $(\AA)$ & Bond & Length $(\AA)$ \\
\hline $\mathrm{O}(22)-\mathrm{H}(34)$ & 1.1099 & $\mathrm{C}(18)-\mathrm{H}(28)$ & 1.14 & $\mathrm{O}(12)-\mathrm{Pd}(21)$ & 2.087 & $\mathrm{C}(5)-\mathrm{N}(6)$ & 1.5108 \\
$\mathrm{O}(22)-\mathrm{H}(33)$ & 1.11 & $\mathrm{C}(17)-\mathrm{H}(27)$ & 1.1399 & $\mathrm{C}(14)-\mathrm{C}(11)$ & 1.5573 & $\mathrm{C}(4)-\mathrm{C}(7)$ & 1.5418 \\
$\mathrm{Cl}(23)-\mathrm{Pd}(21)$ & 2.3458 & $\mathrm{C}(17)-\mathrm{C}(18)$ & 1.5354 & $\mathrm{C}(11)-\mathrm{O}(12)$ & 1.5099 & $\mathrm{C}(4)-\mathrm{C}(5)$ & 1.5446 \\
$\mathrm{O}(22)-\mathrm{Pd}(21)$ & 2.0975 & $\mathrm{~N}(16)-\mathrm{C}(17)$ & 1.5069 & $\mathrm{~N}(9)-\mathrm{C}(11)$ & 1.5149 & $\mathrm{~N}(3)-\mathrm{C}(4)$ & 1.5108 \\
$\mathrm{~N}(20)-\mathrm{H}(32)$ & 1.1101 & $\mathrm{C}(15)-\mathrm{N}(20)$ & 1.5106 & $\mathrm{~N}(8)-\mathrm{H}(26)$ & 1.1067 & $\mathrm{C}(2)-\mathrm{H}(25)$ & 1.1401 \\
$\mathrm{~N}(20)-\mathrm{H}(31)$ & 1.11 & $\mathrm{C}(15)-\mathrm{N}(16)$ & 1.5116 & $\mathrm{~N}(8)-\mathrm{N}(9)$ & 1.4808 & $\mathrm{C}(2)-\mathrm{N}(3)$ & 1.5091 \\
$\mathrm{~N}(20)-\mathrm{Pd}(21)$ & 2.0895 & $\mathrm{C}(14)-\mathrm{C}(15)$ & 1.5571 & $\mathrm{C}(7)-\mathrm{O}(10)$ & 1.5092 & $\mathrm{C}(1)-\mathrm{H}(24)$ & 1.14 \\
$\mathrm{~N}(19)-\mathrm{H}(30)$ & 1.1079 & $\mathrm{C}(18)-\mathrm{N}(13)$ & 1.5082 & $\mathrm{C}(7)-\mathrm{N}(8)$ & 1.5095 & $\mathrm{~N}(6)-\mathrm{C}(1)$ & 1.5095 \\
$\mathrm{~N}(19)-\mathrm{H}(29)$ & 1.11 & $\mathrm{~N}(13)-\mathrm{C}(14)$ & 1.5106 & $\mathrm{C}(5)-\mathrm{N}(19)$ & 1.5108 & $\mathrm{C}(1)-\mathrm{C}(2)$ & 1.539 \\
\hline
\end{tabular}


Table S10. Bonds angles $\left({ }^{\circ}\right)$ of $\left[\mathrm{Pd}(\mathrm{APA})\left(\mathrm{H}_{2} \mathrm{O}\right) \mathrm{Cl}\right] \cdot 1 / 2 \mathrm{EtOH}$ using DFT-method from $\mathrm{DMOL}^{3}$ calculations.

\begin{tabular}{|c|c|c|c|c|c|}
\hline Angle & Degree $\left({ }^{\circ}\right)$ & Angle & Degree $\left({ }^{\circ}\right)$ & Angle & Degree $\left({ }^{\circ}\right)$ \\
\hline $\mathrm{H}(34)-\mathrm{O}(22)-\mathrm{Pd}(21)$ & 109.4642 & $\mathrm{C}(17)-\mathrm{C}(18)-\mathrm{N}(13)$ & 119.9035 & $\mathrm{~N}(9)-\mathrm{N}(8)-\mathrm{C}(7)$ & 119.82 \\
\hline $\mathrm{H}(33)-\mathrm{O}(22)-\mathrm{Pd}(21)$ & 109.613 & $\mathrm{H}(27)-\mathrm{C}(17)-\mathrm{C}(18)$ & 120.1288 & $\mathrm{O}(10)-\mathrm{C}(7)-\mathrm{N}(8)$ & 119.7379 \\
\hline $\mathrm{Cl}(23)-\mathrm{Pd}(21)-\mathrm{O}(22)$ & 89.8849 & $\mathrm{H}(27)-\mathrm{C}(17)-\mathrm{N}(16)$ & 120.1279 & $\mathrm{O}(10)-\mathrm{C}(7)-\mathrm{C}(4)$ & 120.8417 \\
\hline $\mathrm{Cl}(23)-\mathrm{Pd}(21)-\mathrm{N}(20)$ & 179.3931 & $\mathrm{C}(18)-\mathrm{C}(17)-\mathrm{N}(16)$ & 119.7434 & $\mathrm{~N}(8)-\mathrm{C}(7)-\mathrm{C}(4)$ & 119.4171 \\
\hline $\mathrm{Cl}(23)-\mathrm{Pd}(21)-\mathrm{O}(12)$ & 90.4317 & $\mathrm{C}(17)-\mathrm{N}(16)-\mathrm{C}(15)$ & 120.6591 & $C(5)-N(6)-C(1)$ & 120.1962 \\
\hline $\mathrm{O}(22)-\mathrm{Pd}(21)-\mathrm{N}(20)$ & 90.7193 & $\mathrm{~N}(20)-\mathrm{C}(15)-\mathrm{N}(16)$ & 117.897 & $\mathrm{~N}(19)-\mathrm{C}(5)-\mathrm{N}(6)$ & 119.3221 \\
\hline $\mathrm{O}(22)-\mathrm{Pd}(21)-\mathrm{O}(12)$ & 179.545 & $\mathrm{~N}(20)-\mathrm{C}(15)-\mathrm{C}(14)$ & 122.1352 & $\mathrm{~N}(19)-\mathrm{C}(5)-\mathrm{C}(4)$ & 120.8546 \\
\hline $\mathrm{N}(20)-\mathrm{Pd}(21)-\mathrm{O}(12)$ & 88.9638 & $\mathrm{~N}(16)-\mathrm{C}(15)-\mathrm{C}(14)$ & 119.8389 & $\mathrm{~N}(6)-\mathrm{C}(5)-\mathrm{C}(4)$ & 119.8231 \\
\hline $\mathrm{H}(32)-\mathrm{N}(20)-\mathrm{H}(31)$ & 109.7835 & $\mathrm{C}(15)-\mathrm{C}(14)-\mathrm{N}(13)$ & 118.7078 & $C(7)-C(4)-C(5)$ & 121.1058 \\
\hline $\mathrm{H}(32)-\mathrm{N}(20)-\mathrm{Pd}(21)$ & 109.6259 & $\mathrm{C}(15)-\mathrm{C}(14)-\mathrm{C}(11)$ & 123.0671 & $\mathrm{C}(7)-\mathrm{C}(4)-\mathrm{N}(3)$ & 119.0913 \\
\hline $\mathrm{H}(32)-\mathrm{N}(20)-\mathrm{C}(15)$ & 109.8928 & $\mathrm{~N}(13)-\mathrm{C}(14)-\mathrm{C}(11)$ & 118.2251 & $\mathrm{C}(5)-\mathrm{C}(4)-\mathrm{N}(3)$ & 119.8015 \\
\hline $\mathrm{H}(31)-\mathrm{N}(20)-\mathrm{Pd}(21)$ & 109.7371 & $\mathrm{C}(18)-\mathrm{N}(13)-\mathrm{C}(14)$ & 121.1457 & $\mathrm{C}(4)-\mathrm{N}(3)-\mathrm{C}(2)$ & 120.2436 \\
\hline $\mathrm{H}(31)-\mathrm{N}(20)-\mathrm{C}(15)$ & 109.7275 & $\mathrm{Pd}(21)-\mathrm{O}(12)-\mathrm{C}(11)$ & 107.612 & $\mathrm{H}(25)-\mathrm{C}(2)-\mathrm{N}(3)$ & 120.0226 \\
\hline $\operatorname{Pd}(21)-N(20)-C(15)$ & 108.0494 & $\mathrm{C}(14)-\mathrm{C}(11)-\mathrm{O}(12)$ & 121.8715 & $\mathrm{H}(25)-\mathrm{C}(2)-\mathrm{C}(1)$ & 120.0318 \\
\hline $\mathrm{H}(30)-\mathrm{N}(19)-\mathrm{H}(29)$ & 119.8485 & $\mathrm{C}(14)-\mathrm{C}(11)-\mathrm{N}(9)$ & 120.5024 & $\mathrm{~N}(3)-\mathrm{C}(2)-\mathrm{C}(1)$ & 119.9452 \\
\hline $\mathrm{H}(30)-\mathrm{N}(19)-\mathrm{C}(5)$ & 120.3039 & $\mathrm{O}(12)-\mathrm{C}(11)-\mathrm{N}(9)$ & 117.5862 & $\mathrm{H}(24)-\mathrm{C}(1)-\mathrm{N}(6)$ & 120.0049 \\
\hline $\mathrm{H}(29)-\mathrm{N}(19)-\mathrm{C}(5)$ & 119.8476 & $\mathrm{C}(11)-\mathrm{N}(9)-\mathrm{N}(8)$ & 122.2534 & $\mathrm{H}(24)-\mathrm{C}(1)-\mathrm{C}(2)$ & 120.0056 \\
\hline $\mathrm{H}(28)-\mathrm{C}(18)-\mathrm{C}(17)$ & 120.0458 & $\mathrm{H}(26)-\mathrm{N}(8)-\mathrm{N}(9)$ & 120.5353 & $\mathrm{~N}(6)-\mathrm{C}(1)-\mathrm{C}(2)$ & 119.9892 \\
\hline $\mathrm{H}(34)-\mathrm{O}(22)-\mathrm{Pd}(21)$ & 109.4642 & $\mathrm{C}(17)-\mathrm{C}(18)-\mathrm{N}(13)$ & 119.9035 & $\mathrm{~N}(9)-\mathrm{N}(8)-\mathrm{C}(7)$ & 119.82 \\
\hline
\end{tabular}

Table S11. Decomposition steps with the temperature range and weight loss for $\mathrm{Cu}^{2+}$ complex of APA.

\begin{tabular}{|c|c|c|c|c|c|}
\hline \multirow{2}{*}{ Compound } & \multirow{2}{*}{ Decomp. Step } & \multirow{2}{*}{ Temperature Range $\left({ }^{\circ} \mathrm{C}\right)$} & \multirow{2}{*}{ Remove Species } & \multicolumn{2}{|c|}{ Wt. Loss } \\
\hline & & & & $\%$ (Calcd.) & $\%$ Found \\
\hline \multirow{6}{*}[\mathrm{Cu}_{2}(\text{APA-H})(\mathrm{H}_{2}\mathrm{O})\mathrm{Cl}_{3}]{$\cdot \mathrm{H}_{2} \mathrm{O}$} & $1^{\text {st }}$ & $32-102$ & $-\left(\mathrm{H}_{2} \mathrm{O}\right)$ & 3.3 & 3.3 \\
\hline & $2^{\text {nd }}$ & $102-246$ & $-\left(\mathrm{C}_{4} \mathrm{H}_{4} \mathrm{~N}_{3}+\mathrm{Cl}+\mathrm{H}_{2} \mathrm{O}\right)$ & 27.2 & 27.1 \\
\hline & $3^{\text {rd }}$ & $247-336$ & $-\left(\mathrm{C}_{4} \mathrm{H}_{3} \mathrm{~N}_{3}\right)$ & 17.2 & 17.1 \\
\hline & $4^{\text {th }}$ & $336-416$ & $-(2 \mathrm{HCl})$ & 13.4 & 14.1 \\
\hline & $5^{\text {th }}$ & $417-569$ & $-\left(\mathrm{N}_{2}+\mathrm{C}\right)$ & 7.4 & 7.3 \\
\hline & residue & $====$ & {$\left[\mathrm{Cu}_{2}(\mathrm{O})_{2}\right]+\mathrm{C}$} & 31.5 & 31.1 \\
\hline
\end{tabular}

